\title{
Organic metamorphism as a key for reconstructing tectonic processes: a case study from the Austroalpine unit (Eastern Alps)
}

\author{
Gerd Rantitsch $^{1}$ (C) Christoph Iglseder ${ }^{2} \cdot$ Ralf Schuster $^{2} \cdot$ Marianne Sophie Hollinetz $^{3} \cdot$ Benjamin Huet $^{2}$. \\ Manuel Werdenich ${ }^{3}$
}

Received: 9 March 2020 / Accepted: 12 June 2020 / Published online: 3 July 2020

(c) The Author(s) 2020

\begin{abstract}
At the northwestern margin of the Gurktal Alps (Eastern Alps), Eoalpine (Cretaceous) thrusting of carbonaceous material (CM) bearing metasediments formed a very low- to low-grade metamorphic nappe stack above higher-grade metamorphic basement nappes. Sedimentary burial as well as progressive metamorphism transformed the enclosed CM to anthracite, metaanthracite and semigraphite. In a kinematically well-constrained section at the northwestern frontal margin of the nappe stack, this transformation has been investigated by vitrinite reflectance measurements and Raman spectroscopy of carbonaceous materials (RSCM). Automated, interactive fitting of Raman spectra estimates the metamorphic peak temperatures in a complete section through the upper part of the Upper Austroalpine unit. A RSCM trend indicates a temperature profile of ca. $250-600{ }^{\circ} \mathrm{C}$. The top part of the gradient is reconstructed by one-dimensional thermal modeling. The certainty of ca. $\pm 25^{\circ} \mathrm{C}$ at a confidence level of 0.9 resembles the data variability within a sample location. Due to the large calibration range, the method is able to reconstruct a thermal crustal profile in space and time. The study highlights the versatility of RSCM, which characterizes almost $250 \mathrm{Ma}$ of a complex and polyphase tectonic history. RSCM data characterize the Variscan metamorphic grade in nappes now imbricated in the Eoalpine nappe stack. They additionally constrain a numerical model which emphasizes the significance of an increased thermal gradient in a continental margin towards the western Neotethyan ocean during Permo-Triassic lithospheric extension. It finally characterizes the Eoalpine metamorphic gradient during nappe stacking and a significant metamorphic jump related to exhumation and normal faulting.
\end{abstract}

Keywords Eastern Alps · Upper Austroalpine Unit · Gurktal Alps · Organic metamorphism · Raman spectroscopy · Geothermometry

\section{Introduction}

The metamorphic structure of a nappe pile reflects the spatial and temporal evolution of tectonic processes that shaped its history. To investigate it, petrological methods applying equilibrium thermodynamics on coexisting mineral phases

Gerd Rantitsch

gerd.rantitsch@unileoben.ac.at

Christoph Iglseder

christoph.Iglseder@geologie.ac.at

Ralf Schuster

ralf.schuster@geologie.ac.at

Marianne Sophie Hollinetz

marianne.sophie.hollinetz@univie.ac.at

Benjamin Huet

benjamin.huet@geologie.ac.at are applied on metamorphic rocks formed at deeper crustal levels (e.g. Lanari and Duesterhoeft 2019, and references therein), while diverse low-temperature thermometers (clay mineralogy, organic petrography and geochemistry) and thermochronometers are used to investigate the near-surface parts of a crustal profile (e.g. Dunkl et al. 2011; Ferreiro

Manuel Werdenich

manuel.werdenich@gmx.at

1 Montanuniversität Leoben, Lehrstuhl für Geologie und Lagerstättenlehre, Peter-Tunner Straße 5, 8700 Leoben, Austria

2 Geologische Bundesanstalt Wien, Neulinggasse 38, 1030 Wien, Austria

3 Department für Geodynamik und Sedimentologie, Universität Wien, Althanstraße 14, 1090 Wien, Austria 
Mählmann et al. 2012). Both approaches work best if a single monocyclic tectono-metamorphic event is explored. Their combination is however hampered by a methodological gap in the temperature range between $150{ }^{\circ} \mathrm{C}$ and $350{ }^{\circ} \mathrm{C}$, bridged by Raman spectroscopy of carbonaceous material (RSCM) thermometry.

Vitrinite reflectance data are a result of temperature through time and cannot directly translated into a specific temperature. In contrast, RSCM thermometry (Beyssac et al. 2002b) estimates low grade metamorphic peak temperatures. This method is now routinely used for characterizing the thermal structure of orogens and sedimentary basins (e.g. Angiboust et al. 2009; Souche et al. 2012; Scharf et al. 2013; Fauconnier et al. 2014; Vacherat et al. 2014). However, if a RSCM thermometer is not accurately calibrated (see Lünsdorf et al. 2014) or if the effects of strain (Barzoi 2015) are underestimated, major problems arise. This was claimed by Ferreiro Mählmann and Le Bayon (2016) to explain the controversial metamorphic map patterns of the Swiss Glarus Alps, where vitrinite reflectance discontinuities are not mirrored by RSCM data (see also Ferreiro Mählmann et al. 2012). To avoid major methodological problems of RSCM thermometry (Lünsdorf et al. 2014), Lünsdorf et al. (2017) proposed the use of the IFORS ("Interactive fitting of Raman spectra”) software (Lünsdorf and Lünsdorf 2016) as a new technique to analyze Raman spectra of CM. In this contribution, we provide a case study, demonstrating the benefits of this approach in the analysis of a regional metamorphic temperature pattern, covering very low- to medium-grade metamorphic conditions never explored before by a single geothermometric method.

For this purpose, the Upper Austroalpine nappe stack in the northwestern part of the Gurktal Alps was selected (Fig. 1). This nappe stack consists of rocks showing a very wide range of metamorphic conditions, from diagenesis to amphibolite-facies (Hoinkes et al. 1999; Oberhänsli et al. 2004) formed during the Eoalpine (Cretaceous) collision within the Adriatic microcontinent (Stüwe and Schuster 2010). It records a long history with pre-, syn- and postEoalpine features (Neubauer 1987; Hoinkes et al. 1999; Koroknai et al. 1999; Schuster and Frank 1999; Thöni 1999; Huet 2015). Any attempt to understand the Eoalpine tectonics requires knowledge of the metamorphic grade and the timing of metamorphism in the individual tectonic units. This is however complicated by the polycyclic history.

The application of classical petrological geothermometric methods provided major constraints for reconstructing the upper greenschist- to ultrahigh-pressure eclogite-facies metamorphic zonation in the metamorphic core zone of an orogen, here represented by the Eoalpine high-pressure

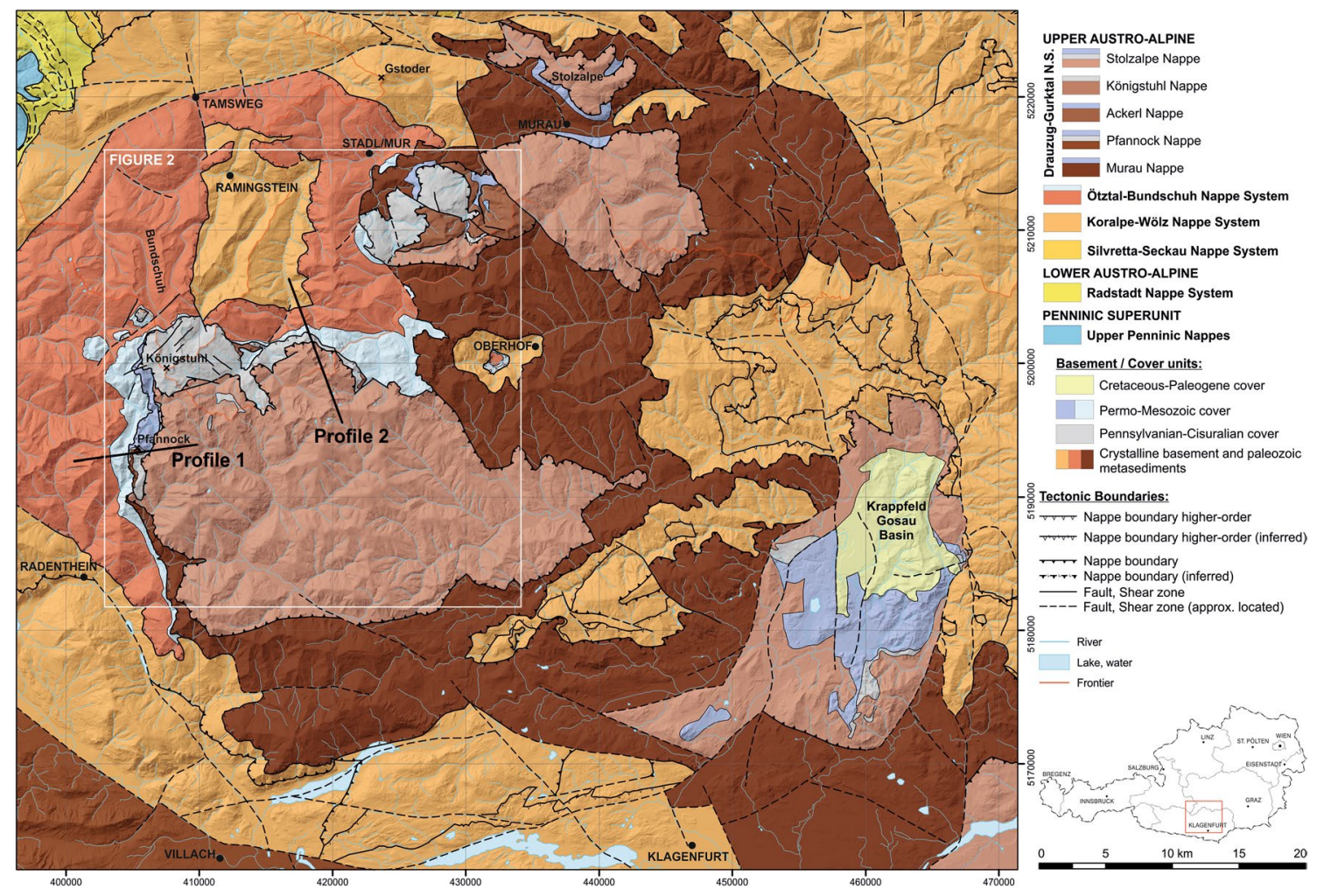

Fig. 1 Simplified geological map of the study area modified from Iglseder (2019). The nappe system nomenclature follows Schmid et al. (2004) and Froitzheim et al. (2008). The political borders of Austria are given as a geographic reference (Coordinate system: UTM 33 N, EPSG 32633 ) 
belt (Janák et al. 2015), which derived from the tectonic lower plate and traces the Cretaceous suture (Schmid et al. 2004). Major units of the tectonically overlying upper-plate segment, widely exposed in the study area, are however composed of very low-grade to lower greenschist-facies metamorphosed Paleozoic sediments (Hoinkes et al. 1999; Oberhänsli et al. 2004). Due to the methodological gap, their peak temperatures have not been accurately constrained until now. The investigated section covers the nappe stack above the eclogite bearing units (Schmid et al. 2004). As carbonaceous material $(\mathrm{CM})$ is present in all implicated structural units, organic metamorphism is investigated in an initially ca. $35 \mathrm{~km}$ thick (corresponding to peak pressure of 10 kbar, Koroknai et al. 1999; Schuster and Frank 1999) profile, bridging the methodological gap between petrological geothermometers, applied in the deeper crust, and kinetic models of organic maturation, applied near to the surface. The study data thus provide new evidence to understand the complex tectonic history of the Upper Austroalpine nappe stack.

RSCM data are used to cover the full temperature range of the rocks, verified by phase equilibrium modeling, and vitrinite reflectance data constrain the Permo-Mesozoic thermal evolution of the nappe stack. The study data also evaluate the limits of organic maturity data (vitrinite reflectance) in the temperature range of $200-400{ }^{\circ} \mathrm{C}$ and the upper limit of the RSCM calibration above $500^{\circ} \mathrm{C}$.

\section{Geological setting}

The nappe stack in the northwestern part of the Gurktal Alps (Fig. 1) was assembled during Cretaceous WNW directed thrusting (Tollmann 1977; Neubauer 1980, 1987; von Gosen et al. 1985; Schimana 1986; von Gosen 1989; Ratschbacher and Neubauer 1989; Koroknai et al. 1999; Schuster and Frank 1999; Huet 2015) in early to middle Late Cretaceous time (Froitzheim et al. 2008). All nappes under discussion belong to the Upper Austroalpine Unit (Schmid et al. 2004), which derived from the Adriatic Microcontinent. The lowermost element of the investigated area is the uppermost part of the Koralpe-Wölz Nappe System that was overthrusted by the Ötztal-Bundschuh and Drauzug-Gurktal Nappe Systems, both derived from the Eoalpine upper-plate (Schmid et al. 2004). On either side of the deeply subducted, eclogitebearing nappes in the center of the Koralpe-Wölz Nappe System, the Eoalpine metamorphic gradient decreases to (sub-) greenschist-facies conditions with an inverted metamorphic gradient in the footwall and a normal metamorphic gradient in the hangingwall. Eoalpine thrusting was followed by post middle Late Cretaceous normal faulting, thinning the nappe pile with normal faults dominantly dipping towards the east (Neubauer 1987; Ratschbacher and Neubauer 1989;
Koroknai et al. 1999; Huet 2015). During this extensional event, Gosau Basins (middle Late Cretaceous to Eocene) formed as collapse basins synchronously with the exhumation of formerly deeply buried basement rocks (Neubauer et al. 1995; Fügenschuh et al. 2000; Rantitsch et al. 2005; Krenn et al. 2008).

The investigated individual nappes are composed of different types of basement and characterized by different stratigraphic ranges of their post-Variscan cover (Fig. 1). Major parts of the basement record a polyphase history including Ordovician, Carboniferous (Variscan), Permo-Triassic and/ or Cretaceous (Eoalpine) tectono-metamorphic imprints (Neubauer 1987; Hoinkes et al. 1999; Koroknai et al. 1999; Schuster and Frank 1999; Thöni 1999; Huet 2015). For this reason constraining the Eoalpine metamorphic conditions is sometimes complicated. The post-Variscan cover deposited in three sedimentary cycles. The oldest cycle is represented by Pennsylvanian (Stangnock Formation) to Cisuralian (Werchzirm Formation) molasse type sediments deposited within an intramontane basin (Krainer 1993). The next one comprises upper Permian to Lower Triassic siliciclastic transgressional series (e.g. Alpine Verrucano, Lantschfeld quartzite), overlain by Anisian to Jurassic successions dominated by carbonaceous platform sediments (Pistotnik 1973/1974). During the Eoalpine event, sediments of both cycles experienced deformation and prograde metamorphism. The last cycle, represented by Santonian to Eocene sediments of the Gosau Group postdates the Eoalpine metamorphic peak. It includes a transgressional sequence unconformably overlying Triassic carbonates, which grade into sediments of a deeper marine basin (Van Hinte 1963).

In the study area, the Gstoder Nappe, the uppermost part of the Koralpe-Wölz Nappe System, is the structurally lowermost element (Fig. 1). It crops out in the Ramingstein Window below the Bundschuh Nappe (Schuster and Frank 1999) and in the Oberhof Window, where it shows an inverted position. The Gstoder Nappe consists predominantly of micaschist with layers of amphibolite, marble and quartzite (Radenthein Complex). A prograde assemblage of garnet, staurolite and kyanite in the metapelites argues for an epidote-amphibolite- to amphibolite-facies Eoalpine metamorphic imprint at ca. $100 \mathrm{Ma}$ (Koroknai et al. 1999; Schuster and Frank 1999).

The Bundschuh Nappe of the Ötztal-Bundschuh Nappe System consists of a basement and an upper Permian to Jurassic cover sequence. Paragneiss and micaschist with intercalations of amphibolite and orthogneiss (BundschuhPriedröf Complex) were affected by amphibolite-facies conditions during the Variscan tectonometamorphic event and an Eoalpine overprint reaching epidote-amphibolite-facies in the structurally lower part (Schimana 1986; Koroknai et al. 1999; Schuster and Frank 1999). Parautochthonous upper Permian to Early Triassic siliciclastics and Triassic 
carbonates (von Gosen et al. 1985) form the main part of the Bundschuh Nappe cover sequence. The uppermost part is composed of impure calcite marble, metaradiolarite and phyllite of Jurassic age ("Phyllonite Zone" in von Gosen et al. 1985). This cover series referred to as Stangalm Mesozoic sensu lato (Iglseder et al. 2019) was metamorphosed at temperatures $>400{ }^{\circ} \mathrm{C}$ (Schimana 1986; von Gosen 1989) during the Cretaceous (Iglseder et al. 2016).

Units above the Bundschuh Nappe belong to the DrauzugGurktal Nappe System (Fig. 1). Micaschist, phyllite, greenschist and carbonate rocks derived from Paleozoic sediments form the basement of the Murau Nappe (Neubauer and Pistotnik 1984), which is locally overlain by an upper Permian to Early Triassic siliciclastic cover. In the basement, upper greenschist- to epidote-amphibolite-facies metamorphic conditions were reached at temperatures from 460 to $500{ }^{\circ} \mathrm{C}$ (von Gosen et al. 1987) to $550-600{ }^{\circ} \mathrm{C}$ (von Gosen et al. 1985; von Gosen 1989; Koroknai et al. 1999). Both a Variscan and an Eoalpine metamorphic imprint have been suggested for the Murau Nappe, but mica K-Ar, ${ }^{40} \mathrm{Ar} /{ }^{39} \mathrm{Ar}$ and $\mathrm{Rb}-\mathrm{Sr}$ ages of ca. 85-90 Ma (Hejl 1984; Neubauer et al. 2003) mainly point to Eoalpine metamorphism.

Tectonically above, the Ackerl Nappe and Pfannock Nappe are laterally discontinuous (Neubauer 1980, 1987; von Gosen et al. 1985). Variscan amphibolite-facies metamorphic micaschist and paragneiss characterize the basement of the Ackerl Nappe, whereas the cover consists of upper Permian siliciclastics to Early Triassic carbonates. In contrast, in the Pfannock Nappe an Ordovician granite (Frimmel 1988) deformed and metamorphosed during the Variscan tectonometamorphic event serves as basement for a Pennsylvanian to Rhaetian cover sequence. Illite crystallinity (von Gosen et al. 1987; Rantitsch and Russegger 2000) and vitrinite reflectance (Rantitsch and Russegger 2000) data indicate very-low grade metamorphic conditions in the fossil bearing metasediments.

The overlying nappes are composed of similar rocks, but were dismembered during Eoalpine thrusting (Huet 2015) into the Königstuhl Nappe and the uppermost Stolzalpe Nappe (Iglseder et al. 2019). Metasiliciclastic rocks (Spielriegel Complex) and various metavolcanic rocks (Kaser Complex) with minor carbonate rocks of their basement derived from Ordovician to Lower Carboniferous sediments (Piller 2014). According to ${ }^{40} \mathrm{Ar}-{ }^{39} \mathrm{Ar}$ age dating, low grade metamorphic conditions were reached during the Variscan event (Iglseder et al. 2016). Coal-bearing Middle to Upper Pennsylvanian (Krainer 1993) slate, sandstone and conglomerate (Stangnock Formation) and Cisuralien slates (Werchzirm Formation) occur in both nappes. They represent intramontane molasse deposits of the Variscan orogeny (Schönlaub 2014). Additionally, southeast of the study area, a Permo-Triassic transgressional sequence is present on top of the Stolzalpe Nappe (Lein 1989). Vitrinite reflectance as well as illite crystallinity data from the post-Variscan cover indicate very-low grade metamorphic conditions of Eoalpine metamorphism (von Gosen et al. 1987; Rantitsch and Russegger 2000). On top of the nappe stack, Santonian to Eocene sediments of the Krappfeld Gosau occur (Neumann 1989; Wilkens 1989).

\section{Samples and methods}

The sample set consists of 111 organic-rich schists, phyllites, slates and anthracites, systematically sampled from all nappes of the study area (Table 1). Stratigraphic and tectonic position of the samples are constrained by detailed geological field mapping data (Iglseder et al. 2019).

Following standard techniques, vitrinite reflectance (Rmax and Rmin, Ro) was determined under oil immersion at a wavelength of $546 \mathrm{~nm}$, obtained through a Leica DMRX microscope with attached TIDAS PMT IV photometer (J\&M Analytics) using a $100 \times$ oil objective. Vitrinite reflectance of selected anthracites was estimated by the reflectance indicating surface according to Kilby (1988).

Petromod 1D software of Schlumberger Ltd. was used to model the Permo-Mesozoic subsidence of the sedimentary sequence now found on top of the Stolzalpe Nappe by a forward event-stepping approach as described in Hantschel and Kauerauf (2009). For the calculation of vitrinite reflection the EASY\%Ro approach of Sweeney and Burnham (1990) was applied. Models were calibrated by modifying heat flow and the thickness of eroded sediments until a satisfactory fit between measured and calculated vitrinite reflection was obtained. Rmax values were converted to Ro values according to Koch and Günther (1995).

Carbonaceous matter for the Raman measurements was isolated from organic-rich metasediments by an acid treatment as described by Rantitsch et al. (2004). Raman spectra were acquired by using a Dilor confocal Raman spectrometer equipped with a frequency-doubled Nd-YAG laser (100 $\mathrm{mW}, 532 \mathrm{~nm}$ ) and diffraction gratings of 1800 grooves/ $\mathrm{mm}$ and a Peltier-cooled, slow-scan, CCD matrix-detector. Laser focusing and sample viewing were performed through an Olympus BX 40 microscope fitted with a $10 \times$ longworking distance objective lens. To obtain a better signal to noise ratio five scans with an acquisition time of $30 \mathrm{~s}$ in the $700-2000 \mathrm{~cm}^{-1}$ region were averaged. The band positions were maintained by the use of standard samples. Some samples were analyzed by a Horiba Labram Evolution instrument equipped with a $100 \times$ distance objective lens, collecting two scans with an acquisition time of $20 \mathrm{~s}$ in the $700-2000 \mathrm{~cm}^{-1}$ region. Several spectra (mostly 10-20) were recorded for each sample. Samples with a smaller number of spectra evaluate the consistency of the temperature pattern. 
The numerical analysis of Raman spectra (Beyssac et al. 2002 b) is widely used to estimate low grade-metamorphic temperatures. However, significant methodological problems arise if a lab-specific temperature calibration is used (Lünsdorf et al. 2014). Therefore, the Raman spectra were evaluated by the IFORS approach of Lünsdorf and Lünsdorf (2016), excluding subjectivity in curve-fitting. The obtained results were used to estimate metamorphic temperatures from the regression of the scale total area (STA) parameter against metamorphic temperatures of geothermometrically well-constrained reference samples (Lünsdorf et al. 2017). To avoid any bias arising from the used sample preparation method and instrumental setting, the reference series samples were prepared and analyzed as done with the study samples. RSCM temperatures estimate the peak metamorphic temperature of carbonaceous material. From the estimated STA parameter, they were calculated from a regression line with a confidence of 0.95 (Lünsdorf et al. 2017). The prediction certainty is given by the \pm 0.90 certainty interval. The established RSCM temperature calibration resembles the calibration of Lünsdorf et al. (2017), established by using a different instrumental setup on samples prepared by other methods. This indicates the robustness of this approach. However, the regression line deviates from the $600{ }^{\circ} \mathrm{C}$ calibration data point, indicating a restricted validity of the model at temperatures above $550{ }^{\circ} \mathrm{C}$. The certainty of the temperature estimates depends directly on the certainty of the calibration data. Consequently, the 0.9 confidence level is estimated with ca. $\pm 25^{\circ} \mathrm{C}$. Temperature estimates from replicate samples of the same location are within this interval.

Peak temperature of $550-600{ }^{\circ} \mathrm{C}$ corresponding to garnetstaurolite-kyanite assemblages have been estimated for the Gstoder Nappe (Hoinkes et al. 1999; Koroknai et al. 1999; Schuster and Frank 1999; Kaindl and Abart, 2002) providing a valuable comparison to RSCM at high temperature. One sample (IGL 16/03) presenting a lower temperature peak assemblage (garnet-chloritoid) was selected for phase equilibrium modeling in order to validate the RSCM temperature at the center of the nappe stack. The sample was petrographically and chemically characterized using a FEI Inspect S50 scanning electron microscope and a CAMECA SX5 electron probe microanalyzer, both operating at $15 \mathrm{kV}$ acceleration voltage (Department of Lithospheric Research, University of Vienna, Austria). Pulverized sample material was analyzed in ACME Analytical Laboratories Ltd. (Vancouver, Canada). Major elements were determined by inductively coupled plasma-emission spectroscopy (ICP-ES) of fused sample material. A simplified model bulk derived from the whole rock composition was taken as input for the computation of equilibrium assemblage diagrams using the Theriak-Domino software package (De Capitani and Petrakakis 2010). Calculations were performed in the simplified system MnNCKFMASHT with excess $\mathrm{H}_{2} \mathrm{O}$. A modified THERMOCALC database (Holland and Powell 2011) was used with the following modifications of solution models: ilmenite was modeled as ideal ternary solid solution of geikielite, pyrophanite and ilmenite; for feldspar the model of Fuhrman and Lindsley (1988) using thermodynamic properties of low albite was employed; the white mica model was extended to account for pyrophyllite (Coggon and Holland 2002).

\section{Results}

\section{Vitrinite reflectance}

CM enclosed in metapelites of the Gstoder Nappe and Bundschuh Nappe basement is completely transformed to small graphite flakes. Two samples of the Triassic cover of the Bundschuh Nappe contain vitrinite with a Rmax of ca. 6.5\%. A low vitrinite reflectance $(<2.0 \%$ Rmax $)$ in the Carboniferous cover of the Pfannock Nappe (Table 1) indicates a break in the gradient, both towards the footwall and the hangingwall units. Tectonically above, anthracite from the Upper Carboniferous cover of the Königstuhl Nappe (Stangnock Formation) is characterized by Rmax values between 4.8 and 7.0\% (see also Rantitsch and Russegger 2000). The basement of the Stolzalpe Nappe contains vitrinite with Rmax between 7.1 and 7.4\%. Its Pennsylvanian cover (Stangnock Formation) shows vitrinite reflectance values in the same range as measured in the tectonically underlying Königstuhl Nappe (Table 1). An upward decreasing vitrinite reflectance trend within the Stolzalpe Nappe cover is constrained by values between 1.1 and 1.3\% Ro in Carnian slates (Rantitsch and Russegger 2000) and by values between 0.2 and $0.5 \%$ Ro in Upper Cretaceous to Eocene shales of the Krappfeld Gosau Subgroup (Table 1).

\section{Raman spectroscopy of carbonaceous material}

In the Gstoder Nappe and in the basement of the Bundschuh Nappe, the spectral characteristics indicate the presence of graphite (Rantitsch et al. 2016). Spectra from the Mesozoic cover of the Bundschuh Nappe and the basement rocks of the Murau Nappe are in the field of semigraphite (Rantitsch et al. 2016). Tectonically upward, phyllites from the basement of the Königstuhl Nappe and Stolzalpe Nappe are attributed to the anthracite stage of organic metamorphism.

The spatial pattern of the RSCM temperature estimates (Table 1; Fig. 2) shows a consistent variation of the data demonstrating that the number of collected spectra per sample is sufficient to reconstruct the thermal structure of the study area. The Gstoder Nappe within the Ramingstein Window is characterized by RSCM temperatures in the range 

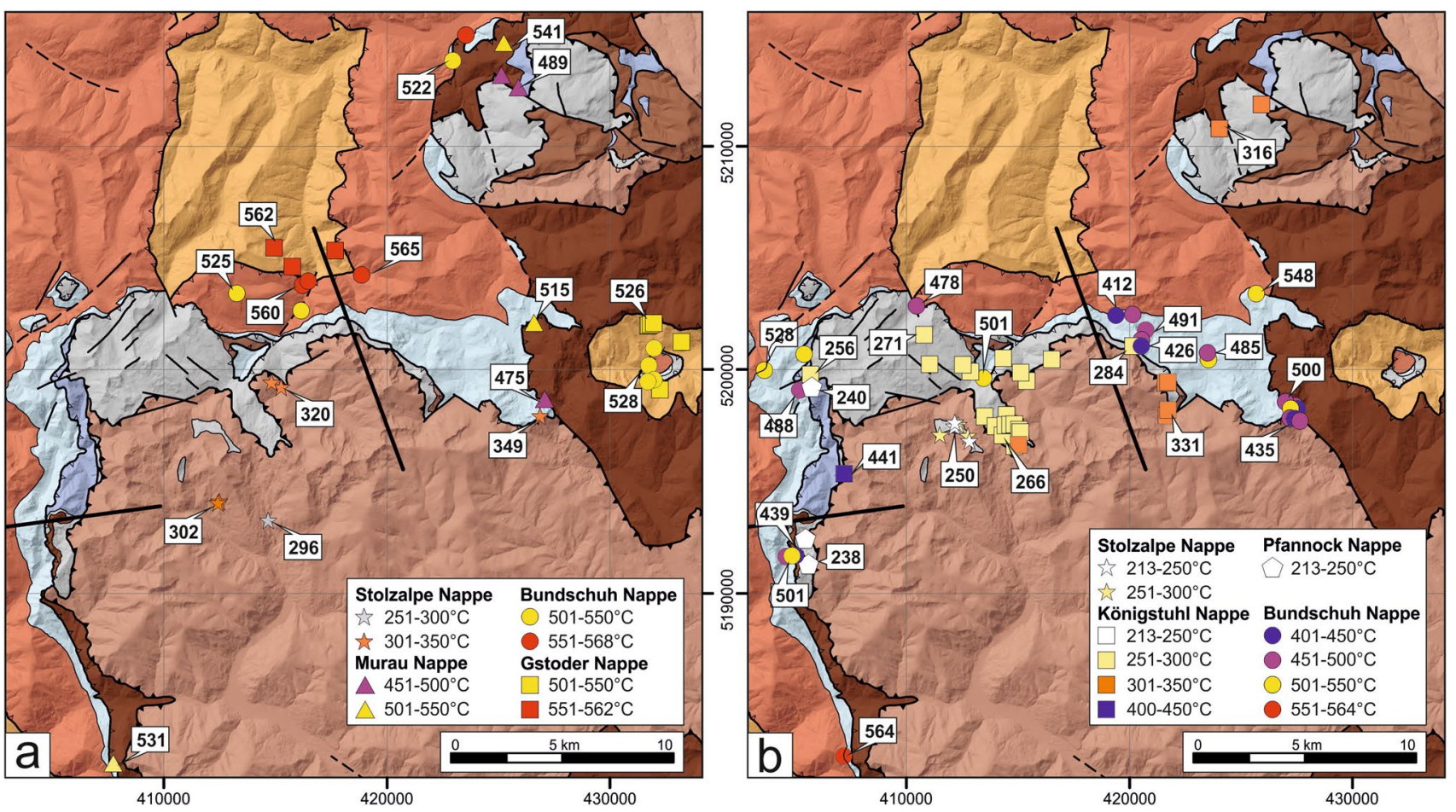

Fig. 2 RSCM temperatures (in ${ }^{\circ} \mathrm{C}$ ) within basement (a) and cover rocks (b) at the northwestern margin of the Gurktal Alps. See Fig. 1 for localization. Coordinate system: UTM 33 N, EPSG 32633

$550-570{ }^{\circ} \mathrm{C}$. Towards the east, within the tectonic window of Oberhof, lower temperatures were estimated. The basement of the Bundschuh Nappe shows RSCM temperatures higher than $550{ }^{\circ} \mathrm{C}$ in the frame of the Ramingstein Window, decreasing upwards in the section and in the Oberhof Window. Within the Permo-Mesozoic cover of the Bundschuh Nappe, temperatures ranging from $564{ }^{\circ} \mathrm{C}$ to ca. $410^{\circ} \mathrm{C}$ are observed. Samples from the basement of the Murau Nappe in the northern part of the study area show RSCM temperatures of $475-540{ }^{\circ} \mathrm{C}$ and within the southwest $530{ }^{\circ} \mathrm{C}$. Much lower temperature estimates of $213-240{ }^{\circ} \mathrm{C}$ were determined in the Pennsylvanian and Permo-Triassic cover of the Pfannock Nappe. Data from the overlying Königstuhl Nappe were measured from samples of its Upper Carboniferous cover. In the main part of the nappe, a continuous increase from ca. $250{ }^{\circ} \mathrm{C}$ in the west to ca. $330{ }^{\circ} \mathrm{C}$ in the east is observed. A slice of this nappe on top of the Pfannock Nappe yields a remarkably higher value of ca. $441^{\circ} \mathrm{C}$. RSCM temperatures of ca. $300{ }^{\circ} \mathrm{C}$ to $320^{\circ} \mathrm{C}$ were determined from the basement of the Stolzalpe Nappe, whereas in the Pennsylvanian cover they are significantly lower with ca. $235-255^{\circ} \mathrm{C}$.

\section{Phase equilibrium modeling}

The garnet-bearing micaschist sample (IGL16/03) from the top of the Bundschuh Nappe contains garnet and chloritoid porphyroblasts in a matrix consisting of chlorite, muscovite, paragonite, quartz and ilmenite (Fig. 3a). Straight phase boundaries indicate chemical equilibrium between these phases at metamorphic peak conditions. Simple chemical zoning in garnet indicates a single-phased mineral growth. A simplified model bulk derived from whole rock analysis was used to calculate an equilibrium assemblage diagram (Fig. 3b). The observed assemblage is reproduced in a narrow $\mathrm{P}-\mathrm{T}$ field at $510-545^{\circ} \mathrm{C}$ and $8-11 \mathrm{kbar}$. This $\mathrm{P}-\mathrm{T}$ field is cross-cut by modeled garnet isopleth corresponding to observed garnet rim compositions determined from electron microprobe analyses at ca. $540{ }^{\circ} \mathrm{C}$ and ca. $10.5 \mathrm{kbar}$. The narrow intersection area of the isopleths indicates robustness of the model and the derived P-T conditions. Following Plunder et al. (2012), a minimum error interval of $\pm 30^{\circ} \mathrm{C}$ and $\pm 1 \mathrm{kbar}$ is assumed.

\section{Thermal 1D modeling}

Thermal 1D modeling of the Permo-Mesozoic cover of the Stolzalpe Nappe reconstructs the Mesozoic thermal history of the Stolzalpe Nappe in greater detail. The boundary conditions of this model are given by published stratigraphic data (Table 2), constraining the Mesozoic subsidence path, the petrophysical properties of the implicated lithotypes, and paleo water depths from environmental reconstructions, controlling the sediment-water-interface 
Fig. 3 Phase equilibrium modeling of garnet bearing micaschist IGL 16/03. a BSE image of sample IGL 16/03 showing the mineral assemblage stable at peak conditions. b Equilibrium assemblage diagram with garnet isopleths (dashed lines) corresponding to observed garnet rim compositions. The stability field of the equilibrium assemblage garnet + chloritoid + ilmenite + chlorite + paragonite and important reactions are highlighted. Mineral abbreviations are used after Whitney and Evans (2010)

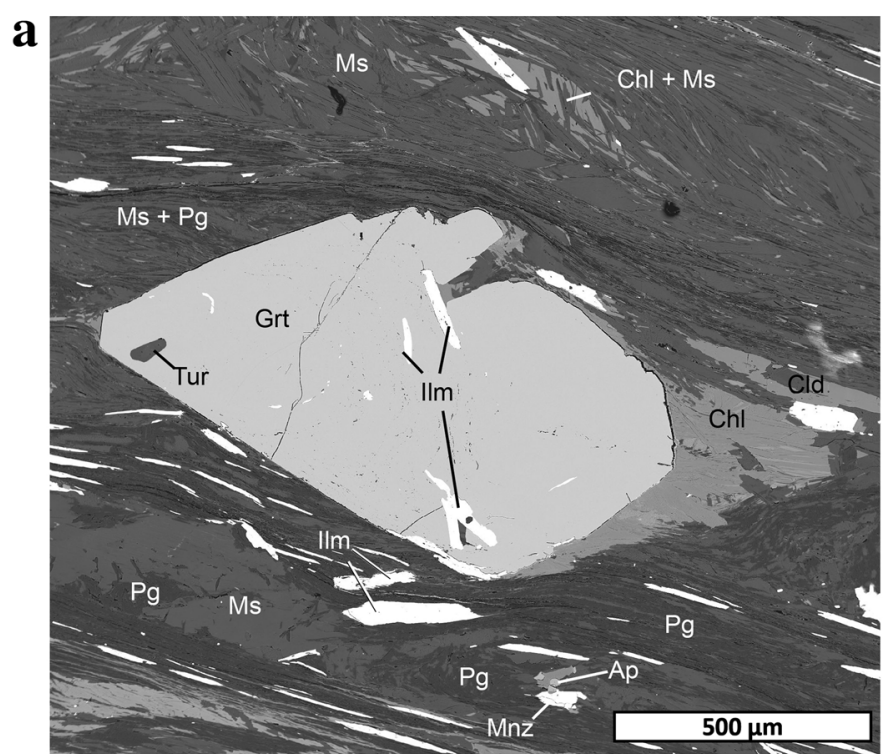

${ }_{12}$

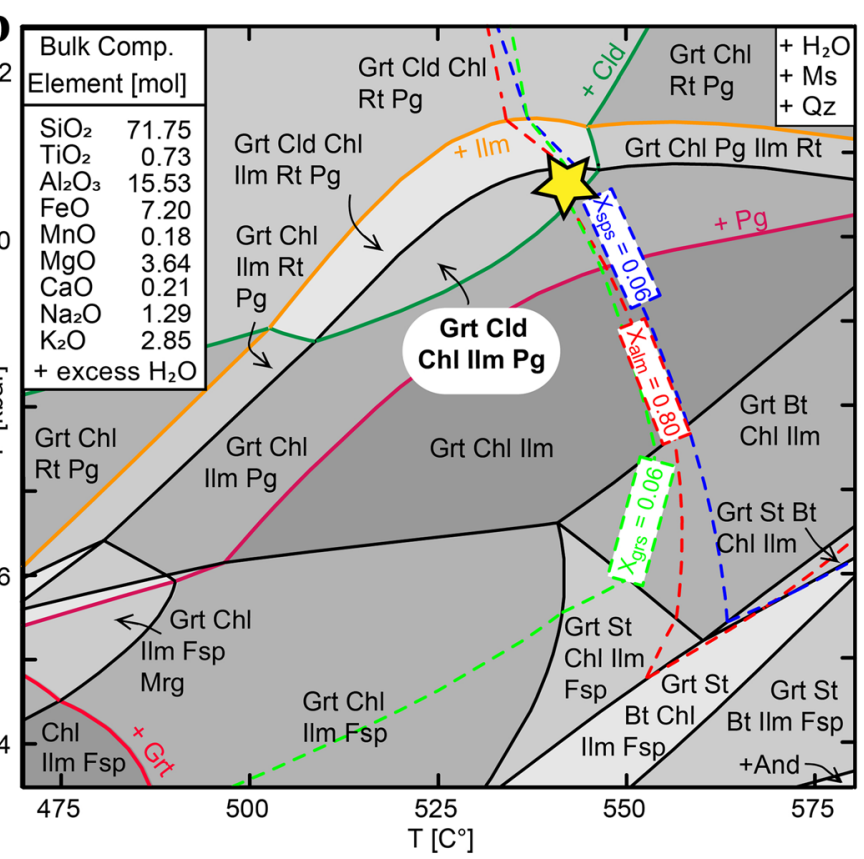

temperature estimate from the Pennsylvanian Stangnock Formation of the Stolzalpe Nappe (Table 1). A Zircon (U-Th-He) age of ca. $75 \mathrm{Ma}$ (Iglseder et al. 2018) dates the cooling of the Stolzalpe Nappe basement below ca. $150{ }^{\circ} \mathrm{C}$ and is linked to the post-orogenic exhumation of the nappe stack in an extensional tectonic regime. Final exhumation occurred during the upper Oligocene to Pliocene (Neubauer et al. 2018; Bartusch and Stüwe 2019).

Since the Rhaetian to Campanian sedimentary cover of the Stolzalpe Nappe is now eroded, its thickness is estimated by comparison to other equivalent sequences. For a reliable thermal model, the paleogeographical fit of the Permo-Mesozoic cover remnants of the Drauzug-Gurktal Nappe System (Stolzalpe Nappe cover, Lienzer Dolomiten, Gailtaler 
Alpen, Dobratsch Range, Northern Karawanken Range) is therefore crucial. In a map view, the Permo-Mesozoic cover remnants appear as fragmented units which were displaced by Jurassic (Schuster and Frank 2000; Schuster et al. 2015) and Oligocene-Miocene (Ratschbacher et al. 1989; Schmidt et al. 1991, 1993) strike-slip tectonics. Reconstructions of the Triassic paleogeography (Bechstädt 1978; Schmidt et al. 1991; Haas et al. 1995; Lein et al. 1997; Schuster and Frank 2000) locate these fragments at the outer passive margin of the western Neotethys. During this time, they were arranged in a close vicinity (e.g. Haas et al. 2020), not far from the Southalpine platform carbonates (Bertotti et al. 1993). The Anisian-Ladinian Wetterstein Formation of the western Lienzer Dolomiten shows a thickness of max. $1700 \mathrm{~m}$ and ca. $1300-1400 \mathrm{~m}$ in the Dobratsch unit of the Gailtaler Alpen (Bechstädt 1978) and the Northern Karawanken Range (Bauer et al. 1983). For the Norian Hauptdolomit Formation, thicknesses vary from max. $3000 \mathrm{~m}$ within the Lienzer Dolomiten (Blau and Schmidt 1990), to 600-700 m in the Northern Karawanken Range (Bauer et al. 1983) and more than $1000 \mathrm{~m}$ in the Gailtaler Alpen (Bechstädt 1978).

Assuming a general heat flow of $50 \mathrm{~mW} / \mathrm{cm}^{2}, 1000 \mathrm{~m}$ thick Campanian to Eocene sandstones and marls and $1200 \mathrm{~m}$ thick dolomites of the Hauptdolomit Formation explain the maturity of the Gosau sediments and the Carnian Raibl Formation (Fig. 4). The thickness of the AnisianLadinian Wetterstein Formation as well as the post-Variscan heat flow had to be varied to explain the maturity of the Pennsylvanian Stangnock Formation. A consistent model (Fig. 4) is given using $1000 \mathrm{~m}$ carbonates of the Wetterstein Formation and applying a significantly raised heat flow of $170 \mathrm{~mW} / \mathrm{cm}^{2}$ during Pennsylvanian to Late Triassic times (310-220 Ma). A sensitivity study demonstrates a confident result within the brackets of the conceptual model uncertainty. To get a model fit, lowering the post-Variscan heat flow would result in a too high Wetterstein Formation thickness. The same is true if the time of high heat flow is shortened. Conversely, a lower Wetterstein Formation thickness would result in an extraordinary high heat flow, not constrained by any geological data. Varying the Upper Oligocene to Pliocene uplift does not influence the modeling results.
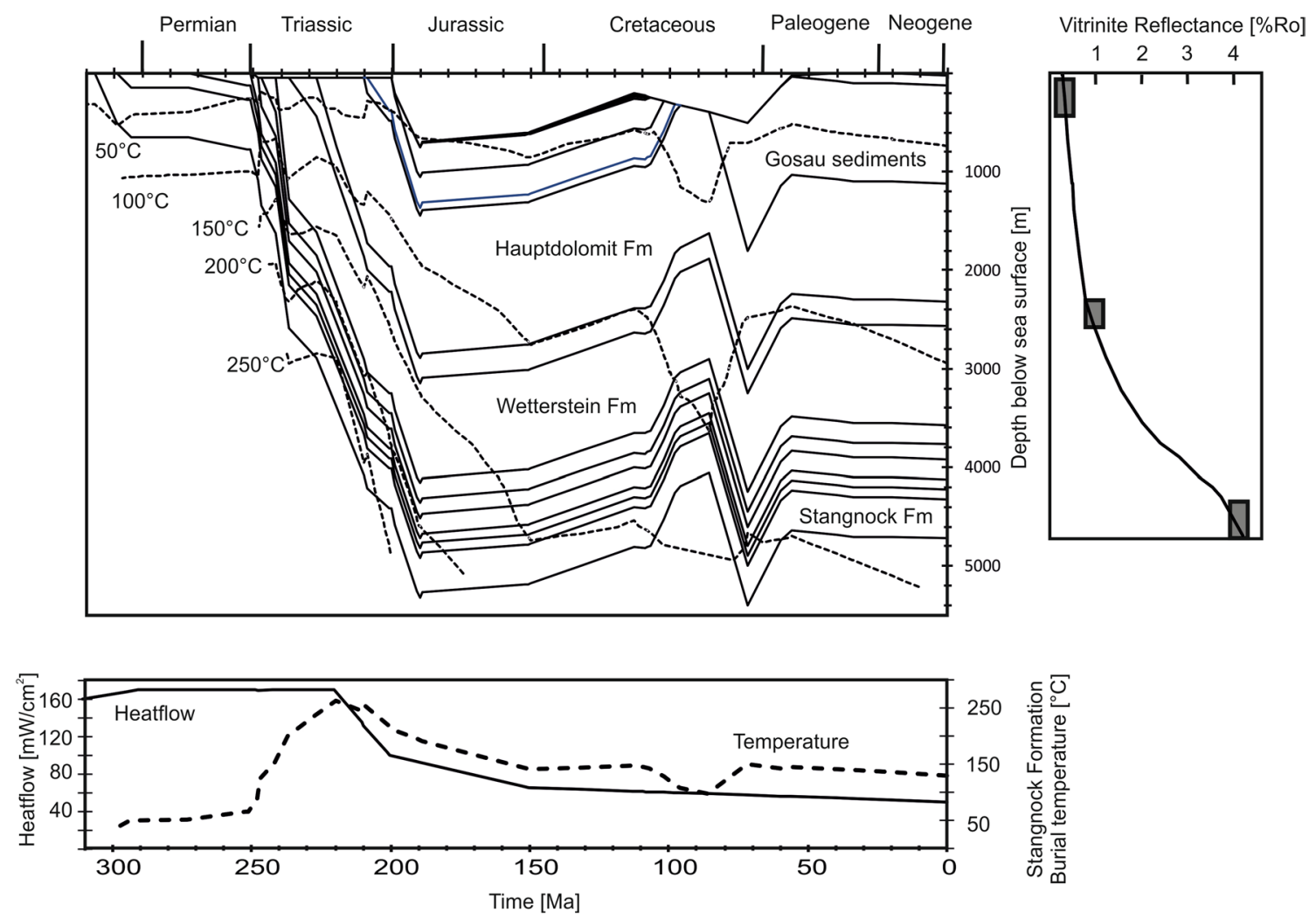

Fig. 4 Thermal model for the subsidence of the Stolzalpe Nappe since Mississippian time calibrated by vitrinite reflectance and burial temperatures of the Stangnock Formation 


\section{Discussion}

\section{Organic metamorphism and validity of the methods}

Metamorphism transforms progressively the composition and microstructure of buried organic matter. During the final stage of organic metamorphism, graphitization changes the turbostratic ordered microstructure of CM into a three-dimensional graphite lattice (Buseck and Huang 1985; Beyssac et al. 2002a). During this stage, metaanthracite and semigraphite (Kwiecińska and Petersen 2004; Rantitsch et al. 2016) emerge as transitional CM types. In very low- to low- grade metamorphic sediments, phytoclasts often occur together as dispersed anthracite and graphite particles in the same sample (Diessel and Offler 1975; Kribek et al. 1994). Thus, the composition of CM present in very low- to low- grade metamorphic metasediments is heterogeneous. To assess the rank of organic metamorphism and to estimate metamorphic temperatures, vitrinite reflectance measurements (Ferreiro Mählmann et al. 2012; Ferreiro Mählmann and Le Bayon 2016) and RSCM (Wopenka and Pasteris 1993; Beyssac et al. 2002b; Henry et al. 2019) provide widely applied standard techniques. The finding of a general correlation of RSCM parameters with vitrinite reflectance (Lünsdorf 2016) suggests that the microstructure of vitrinite controls the bulk Raman signal of CM up to the anthracite rank, but it does not reflect the microstructural properties of semigraphite and graphite (Rantitsch et al. 2016). Consequently, there is an upper limit of vitrinite reflectance as a sensitive temperature indicator of organic metamorphism within the anthracite to semigraphite zone and RSCM remains as the only practicable organic metamorphism parameter at higher temperature conditions.

In the maps showing the metamorphic structure of the Alps (e.g. Oberhänsli et al. 2004) several units attained the anthracite to graphite ranks (e.g. Schramm et al., 1982; Rantitsch 1995, 1997; Ferreiro Mählmann 2001; Rantitsch 2001; Rantitsch and Rainer 2003; Rantitsch et al. 2004; Rantitsch and Judik 2009; Lünsdorf et al. 2012; Rainer et al. 2016; Zerlauth et al. 2016). However, if vitrinite reflectance does not yield accurate peak temperatures within the graphitization zone, these data would give incomplete information about the investigated metamorphic pattern. Furthermore, the application of kinetic vitrinite maturation models (e.g. Sweeney and Burnham 1990) to establish heat flow models could result in a biased understanding of the controlling tectono-thermal processes. This is of particular importance, because vitrinite reflectance is widely used to reconstruct the time-temperature path of metasedimentary rocks in a collisional orogen (for a review see Ferreiro Mählmann et al. 2012). The correlation of vitrinite reflectance and RSCM temperatures within the investigated crustal section therefore provides evidence that temperature of very low- to low- grade metamorphism can be determined by organic maturation studies.

Vitrinite reflectance within the Pennsylvanian cover of the Stolzalpe Nappe of 5.6\%Rmax increases to 7.1\% Rmax within the basement. This is correlated to a RSCM temperature increase from ca. 250 to $>300{ }^{\circ} \mathrm{C}$. Vitrinite reflection values above $6.4 \%$ Rmax are also observed in samples from the Permo-Triassic cover of the Bundschuh Nappe, characterized by significant higher RSCM temperatures in the range of ca. $410-550{ }^{\circ} \mathrm{C}$. Consequently, this maturation range represents the upper limit of vitrinite reflectance as a reliable temperature indicator. Additionally, comparing the data from the Pfannock Nappe and Königstuhl Nappe there is a good correlation in the western part, where an increase from $<2 \%$ to ca. $6 \% \mathrm{Rmax}$ is correlated to an increase of the RSCM temperatures from $213{ }^{\circ} \mathrm{C}$ to $255^{\circ} \mathrm{C}$. However, no certain correlation is visible further to the east, where vitrinite reflection is in the range of 4.8 to $6.5 \% \mathrm{Rmax}$ and the RSCM temperatures are $250{ }^{\circ} \mathrm{C}$ to $320^{\circ} \mathrm{C}$.

These observations are interpreted by a sensitivity loss of vitrinite reflectance as an indicator of organic metamorphism at Rmax values higher than 5-7\% Rmax. In the study area, this rank is achieved in sub-greenschist-facies metamorphic rocks with peak temperatures of ca. $250{ }^{\circ} \mathrm{C}$. At higher temperatures, RSCM is a more reliable method to map the metamorphic pattern. From the Raman data, graphitized CM is found at the base of the Permo-Triassic cover of the Bundschuh Nappe. Consequently, the boundary between the graphite and semigraphite zones (Rantitsch et al. 2016) correlates to $500-550{ }^{\circ} \mathrm{C}$ and ca. 7 kbar. At temperatures lower than $400{ }^{\circ} \mathrm{C}$, the anthracite zone occurs.

Comparison between temperature estimates from RSCM and conventional geothermobarometric methods shows a good agreement. On the one hand, the peak temperature of sample IGL16/03 (Bundschuh Nappe) was estimated at $540 \pm 30{ }^{\circ} \mathrm{C}$ with phase equilibrium modeling and $522 \pm 30{ }^{\circ} \mathrm{C}$ with RSCM geothermometry (Table 1). On the other hand, geothermobarometry and phase equilibrium modeling yielded peak temperatures in the range of 550-600 ${ }^{\circ} \mathrm{C}$ for the Gstoder Nappe (Hoinkes et al. 1999; Koroknai et al. 1999; Kaindl and Abart, 2002; Schuster and Frank 1999) while the RSCM temperatures range between $550{ }^{\circ} \mathrm{C}$ and $570{ }^{\circ} \mathrm{C}$. This indicates the accuracy of the used calibration and the benefit of the IFORS software (Lünsdorf and Lünsdorf 2016) up to a temperature of approximately $570{ }^{\circ} \mathrm{C}$. However, the validity at higher temperatures (at ca. $600{ }^{\circ} \mathrm{C}$ ) has to be tested on well calibrated samples. The robustness of the approaches used in this study allows a confident tectonic interpretation of the presented organic metamorphism dataset. 


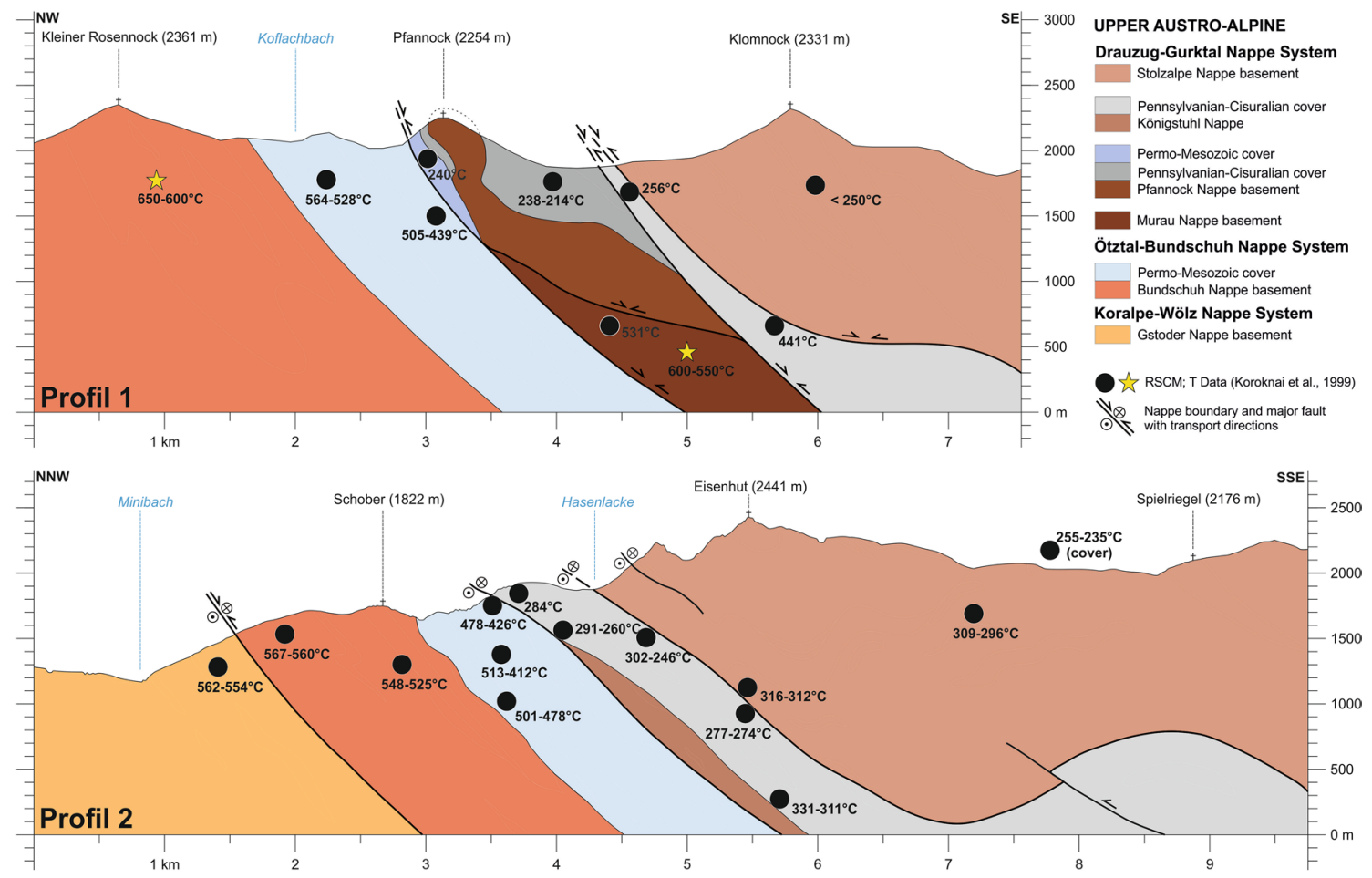

Fig. 5 RSCM temperatures in two key profiles of the nappe stack. The section lines are indicated in Figs. 1 and 2

\section{Pre-Alpine (Variscan) metamorphic pattern}

Most of the basement units were affected by a pre-Alpine, in general Variscan metamorphic imprint. RSCM data are attributed to a pre-Alpine event when the temperatures measured in the basement (Fig. 2a) are significantly higher than in the post-Variscan cover of the same nappe (Fig. 2b). This is the case for the Bundschuh Nappe, the Stolzalpe Nappe and the Pfannock Nappe (Figs. 2, 5, and 6a).

In the investigated area no relics of a pre-Alpine metamorphic imprint have been found in the Gstoder Nappe (Radenthein Complex), but from regional considerations, Schuster and Stüwe (2008) speculated about a lower greenschist-facies Permian overprint. The lack of a PermoMesozoic cover in this nappe prevents further constraints. In the basement of the Bundschuh Nappe (BundschuhPriedröf Complex) amphibolite-facies Variscan conditions are indicated by staurolite-bearing mineral assemblages (Schuster and Frank 1999). The RSCM data yield corresponding temperatures of $548-568{ }^{\circ} \mathrm{C}$ (significantly higher than in the Permo-Mesozoic cover, $412-550{ }^{\circ} \mathrm{C}$ with one outlier at $564{ }^{\circ} \mathrm{C}$ ). Further to the south, temperatures around $600{ }^{\circ} \mathrm{C}$ were reached (Koroknai et al. 1999) but this area is not covered by our dataset. In contrast, for the overlying Murau Nappe evidence for a pre-Alpine metamorphism in the investigated area is hitherto missing. Ductile deformed feldspar indicates that the Pfannock Nappe basement was deformed at temperatures above $450^{\circ} \mathrm{C}$. This implies at least upper greenschist facies conditions in the basement (RSCM temperatures in the cover are $\left.213-240{ }^{\circ} \mathrm{C}\right)$. Similar conditions were reached in the micaschists of the Ackerl Nappe. ${ }^{40} \mathrm{Ar}-{ }^{39} \mathrm{Ar}$ muscovite ages of about 310 Ma constrain cooling after the Variscan metamorphic peak (Neubauer and Dallmeyer 1994). RSCM temperatures measured from basement of the Stolzalpe Nappe are ca. $300-320^{\circ} \mathrm{C}$, indicating lower greenschistfacies conditions.

\section{Eoalpine metamorphic pattern}

The Eoalpine metamorphic temperatures are determined from the cover sequences (Fig. 2) and basement units with indirect arguments indicated by Eoalpine cooling ages (e.g. Gstoder Nappe and Murau Nappe) as well as petrographic aspects (e.g. Bundschuh Nappe). It is important to note, that the Eoalpine peak temperatures may have occurred at different times in the individual units. The map presented in Fig. $6 \mathrm{~b}$ summarizes the Eoalpine metamorphic pattern deduced from our data and the literature.

According to the RSCM measurements, the Gstoder Nappe (Radenthein Complex) was heated to temperatures 


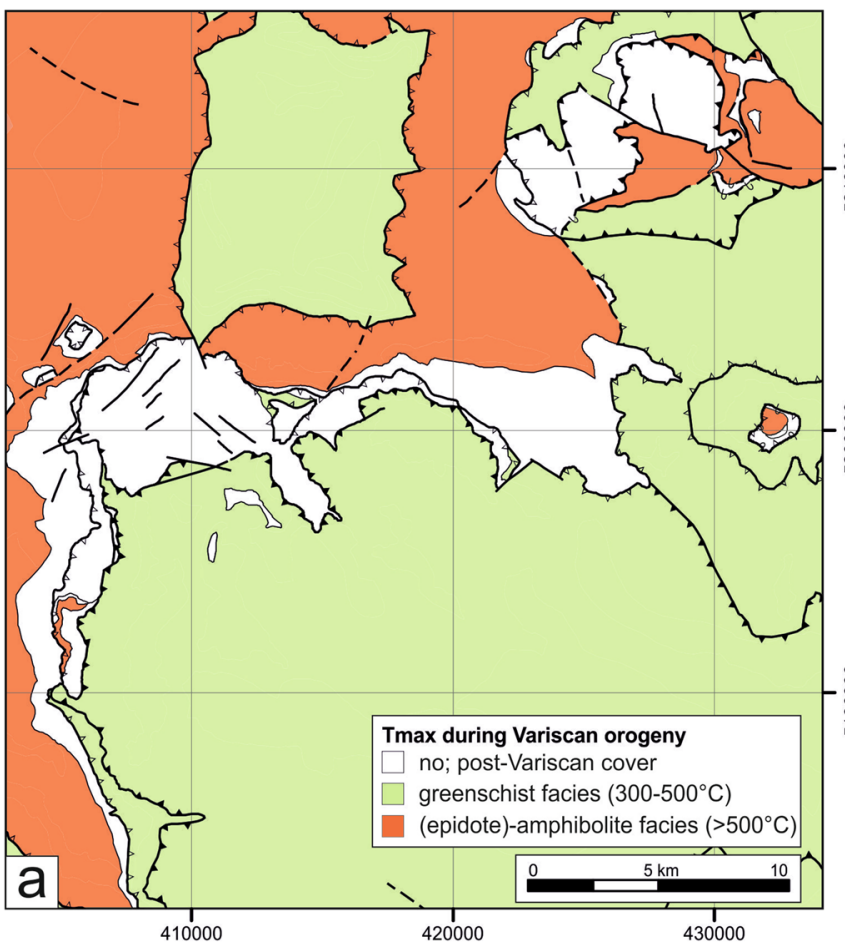

Fig. 6 Distribution of Variscan (a) and Eoalpine (b) metamorphism in the investigated area based on RSCM and literature data (Frey et al. 1999; Hoinkes et al. 1999; Koroknai et al. 1999; Schuster and Frank 1999; Oberhänsli et al. 2004; Bousquet et al. 2012). Color index and limits of metamorphic facies are based on Bousquet et al. (2012) as well as the (frequent) appearance of garnet indicative for the epidote-amphibolite-facies and of staurolite for the amphibolite-

higher than $550{ }^{\circ} \mathrm{C}$. This is in line with phase equilibrium geothermobarometry data of $550-600{ }^{\circ} \mathrm{C}$ and $7-11 \mathrm{kbar}$ (Hoinkes et al. 1999; Koroknai et al. 1999; Kaindl and Abart, 2002; Schuster and Frank 1999) indicative for epidote-amphibolite- to amphibolite-facies metamorphism. Temperatures in the Oberhof Window further to the east are around $516-546{ }^{\circ} \mathrm{C}$ and are marginally lower. Upper greenschist- to amphibolite-facies conditions are reported for the basement of the overlying Bundschuh Nappe (Koroknai et al. 1999; Schuster and Frank 1999). RSCM data from the Permo-Triassic cover are in the range of $410-564{ }^{\circ} \mathrm{C}$, suggesting upper greenschist to epidote-amphibolite facies conditions, in agreement with the equilibrium phase diagram presented above. In the overlying basement of the Murau Nappe, RSCM temperatures of ca. $475-540{ }^{\circ} \mathrm{C}$ were measured in the northeastern part of the investigated area and $531{ }^{\circ} \mathrm{C}$ in the southwest, coinciding with existing geothermometry data of ca. $460-600{ }^{\circ} \mathrm{C}$ (von Gosen et al. 1985, 1987; von Gosen 1989; Koroknai et al. 1999). Much lower RSCM temperatures of ca. $210-240{ }^{\circ} \mathrm{C}$ measured in the cover of the Pfannock Nappe indicate very low-grade metamorphic conditions. Very low-grade to lower greenschistfacies metamorphic conditions with RSCM temperatures in

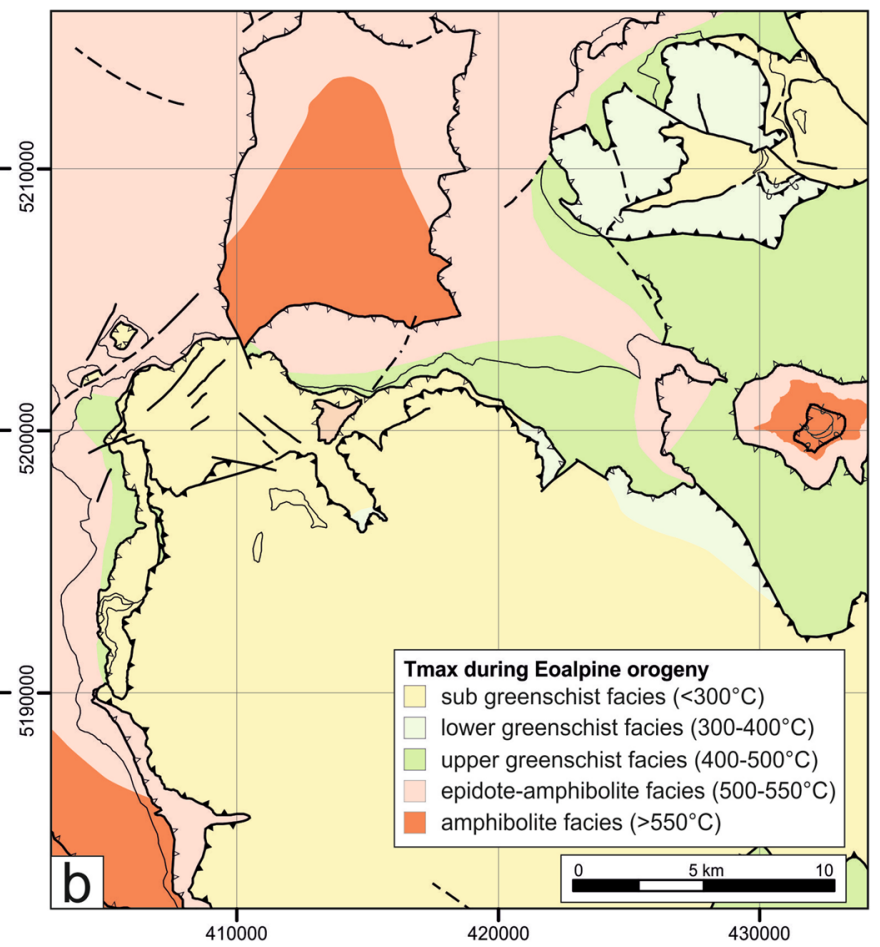

facies. The metamorphic zoning of the Variscan orogeny (a) follows tectonic and lithologic boundaries whereas metamorphism of the Eoalpine orogeny (b) partly superimposes and crosscuts these. A major jump of metamorphic grade follows along the tectonic boundary between the Bundschuh, Murau Nappes in the footwall and the Pfannock, Ackerl, Königstuhl, Stolzalpe Nappes in the hanging wall

the range 250 to $440{ }^{\circ} \mathrm{C}$ also characterize the Königstuhl Nappe. Finally, in the Pennsylvanian cover of the Stolzalpe Nappe, RSCM data indicate condition at $235-255^{\circ} \mathrm{C}$ and even lower temperatures were determined by vitrinite reflectance values in Carnian schists (Rantitsch and Russegger 2000).

In general, the RSCM data indicate an upwards decrease of the Eoalpine metamorphic conditions (Fig. 5). The structurally lower units are characterized by upper greenschist- to amphibolite-facies metamorphism. The metamorphic zoning shows a distinct jump of $100{ }^{\circ} \mathrm{C}$ to $200{ }^{\circ} \mathrm{C}$ in the Eoalpine RSCM temperatures between the Gstoder, Bundschuh and Murau Nappes in the footwall and the overlying units (Fig. 5). Above, within the sub- to lower greenschist-facies units the temperatures range covered is only defined by the RSCM data.

\section{Pre-, syn- and post- Eoalpine tectono-thermal history of the study area}

The metamorphic data reconstruct the thermal history of the investigated area as follows: Late syn- to post-Variscan molasse sediments were deposited in an intramontane basin 
Table 1 RSCM data according to Lünsdorf et al. (2017)

\begin{tabular}{|c|c|c|c|c|c|c|c|c|c|c|c|}
\hline \multirow{3}{*}{ Tectonic Unit } & \multirow{3}{*}{ Sample } & & & \multirow{3}{*}{$\mathbf{N}$} & \multicolumn{2}{|l|}{ RSCM } & \multicolumn{5}{|c|}{ Vitrinite Reflectance } \\
\hline & & \multirow{2}{*}{ Easting } & \multirow{2}{*}{ Northing } & & \multicolumn{2}{|c|}{ Temp $\left({ }^{\circ} \mathrm{C}\right)$} & & \multicolumn{2}{|c|}{$R \max (\%)$} & \multicolumn{2}{|c|}{$\operatorname{Rmin}(\%)$} \\
\hline & & & & & median & cf & $\mathbf{N}$ & mean & sd & mean & sd \\
\hline
\end{tabular}

\begin{tabular}{|c|c|c|c|c|c|c|c|c|c|c|c|}
\hline \multirow{9}{*}{$\begin{array}{c}\text { Gstoder Nappe- } \\
\text { Radenthein Complex }\end{array}$} & IGL14/29 & 417632 & 5205351 & 10 & 558 & 26 & & & & & \\
\hline & IGL14/32 & 414905 & 5205490 & 12 & 562 & 26 & & & & & \\
\hline & IGL14/33 & 415736 & 5204639 & 9 & 554 & 26 & & & & & \\
\hline & IGL16/14 & 432188 & 5199123 & 10 & 527 & 26 & & & & & \\
\hline & IGL17/01 & 431924 & 5202120 & 10 & 517 & 26 & & & & & \\
\hline & IGL17/02 & 431777 & 5202057 & 10 & 526 & 26 & & & & & \\
\hline & IGL17/03 & 431684 & 5202002 & 10 & 519 & 26 & & & & & \\
\hline & MSH17/10B & 433152 & 5201258 & 10 & 546 & 26 & & & & & \\
\hline & MSH17/11B & 431649 & 5201994 & 10 & 516 & 26 & & & & & \\
\hline \multirow{12}{*}{$\begin{array}{l}\text { Bundschuh Nappe - } \\
\text { Bundschuh-Priedröf } \\
\text { Complex }\end{array}$} & IGL14/28 & 418826 & 5204283 & 10 & 565 & 26 & & & & & \\
\hline & IGL14/34 & 416120 & 5202659 & 10 & 548 & 26 & & & & & \\
\hline & IGL16/03 & 422904 & 5213868 & 10 & 522 & 26 & & & & & \\
\hline & IGL16/19 & 431885 & 5199600 & 10 & 516 & 26 & & & & & \\
\hline & IGL16/20 & 431921 & 5199602 & 7 & 528 & 26 & & & & & \\
\hline & IGL16/21 & 431932 & 5199569 & 10 & 528 & 26 & & & & & \\
\hline & IGL16/22 & 431924 & 5201002 & 9 & 515 & 26 & & & & & \\
\hline & IGL16/25 & 416440 & 5204004 & 10 & 560 & 26 & & & & & \\
\hline & IGL16/26 & 416180 & 5203798 & 10 & 567 & 26 & & & & & \\
\hline & IGL16/48 & 413245 & 5203439 & 10 & 525 & 26 & & & & & \\
\hline & IGL18/06A & 423495 & 5214996 & 20 & 568 & 30 & & & & & \\
\hline & MSH17/18B & 431685 & 5200206 & 10 & 518 & 26 & & & & & \\
\hline \multirow{24}{*}{$\begin{array}{l}\text { Bundschuh Nappe - } \\
\text { Stangalm Mesozoic }\end{array}$} & IGL12/70 & 413426 & 5199630 & 3 & 501 & 26 & & & & & \\
\hline & IGL13/23 & 419346 & 5202448 & 8 & 412 & 25 & & & & & \\
\hline & IGL13/59 & 420107 & 5202486 & 10 & 485 & 26 & & & & & \\
\hline & IGL13/80 & 420680 & 5201801 & 10 & 491 & 26 & & & & & \\
\hline & IGL14/44 & 423455 & 5200681 & 10 & 513 & 26 & & & & & \\
\hline & IGL14/45 & 423492 & 5200485 & 10 & 485 & 26 & & & & & \\
\hline & IGL15/24 & 420489 & 5201185 & 10 & 426 & 26 & & & & & \\
\hline & IGL16/27 & 425639 & 5203418 & 10 & 548 & 26 & & & & & \\
\hline & IGL16/38 & 405002 & 5191717 & 9 & 439 & 26 & 17 & 6.65 & 0.55 & 3.24 & 0.86 \\
\hline & IGL16/39 & 404833 & 5191687 & 10 & 481 & 26 & & & & & \\
\hline & IGL16/41 & 404730 & 5191660 & 10 & 501 & 26 & & & & & \\
\hline & IGL16/54 & 410416 & 5202882 & 8 & 478 & 26 & & & & & \\
\hline & IGL16/56 & 420486 & 5201180 & 10 & 478 & 26 & 50 & 6.40 & 0.36 & 4.91 & 0.28 \\
\hline & IGL17/22 & 426968 & 5198596 & 10 & 460 & 26 & & & & & \\
\hline & IGL18/03 & 426899 & 5198530 & 20 & 500 & 29 & & & & & \\
\hline & IGL18/11 & 407392 & 5182790 & 20 & 564 & 34 & & & & & \\
\hline & IGL18/15 & 427020 & 5197952 & 20 & 482 & 34 & & & & & \\
\hline & IGL18/18 & 427185 & 5197951 & 20 & 446 & 47 & & & & & \\
\hline & IGL19/06 & 427556 & 5197785 & 20 & 435 & 33 & & & & & \\
\hline & IGL19/13 & 427333 & 5198459 & 18 & 519 & 34 & & & & & \\
\hline & IGL19/14 & 427367 & 5198421 & 20 & 435 & 33 & & & & & \\
\hline & N4-1 & 403630 & 5199526 & 10 & 528 & 26 & & & & & \\
\hline & N28 & 405413 & 5200206 & 10 & 505 & 26 & & & & & \\
\hline & N53 & 405313 & 5198743 & 10 & 488 & 26 & & & & & \\
\hline
\end{tabular}


Table 1 (continued)

\begin{tabular}{|c|c|c|c|c|c|c|c|c|c|c|c|}
\hline \multirow{3}{*}{ Tectonic Unit } & \multirow{3}{*}{ Sample } & \multirow{3}{*}{ Easting } & \multirow{3}{*}{ Northing } & \multirow{3}{*}{$\mathbf{N}$} & \multicolumn{2}{|l|}{ RSCM } & \multicolumn{5}{|c|}{ Vitrinite Reflectance } \\
\hline & & & & & \multicolumn{2}{|c|}{ Temp $\left({ }^{\circ} \mathrm{C}\right)$} & \multirow{2}{*}{$\mathbf{N}$} & \multicolumn{2}{|c|}{$\operatorname{Rmax}(\%)$} & \multicolumn{2}{|c|}{$\operatorname{Rmin}(\%)$} \\
\hline & & & & & median & cf & & mean & sd & mean & sd \\
\hline \multirow{6}{*}{ Murau Nappe } & IGL16/09 & 425847 & 5212661 & 10 & 489 & 26 & & & & & \\
\hline & IGL16/11 & 425087 & 5213215 & 10 & 494 & 26 & & & & & \\
\hline & IGL17/26 & 426711 & 5198738 & 10 & 475 & 26 & & & & & \\
\hline & IGL18/05 & 425187 & 5214638 & 20 & 541 & 30 & & & & & \\
\hline & IGL18/12 & 407507 & 5182663 & 20 & 531 & 39 & & & & & \\
\hline & IGL18/19 & 426538 & 5202109 & 20 & 515 & 34 & & & & & \\
\hline \multirow{3}{*}{$\begin{array}{l}\text { Pfannock Nappe- } \\
\text { Stangnock Formation }\end{array}$} & IGL14/22 & 405452 & 5192486 & 7 & 213 & 25 & 50 & 1.56 & 0.20 & 0.96 & 0.18 \\
\hline & IGL16/42 & 405576 & 5191341 & 11 & 238 & 25 & 50 & 1.37 & 0.11 & 1.11 & 0.11 \\
\hline & N49 & 405569 & 5198800 & 10 & 240 & 25 & & & & & \\
\hline \multirow{36}{*}{$\begin{array}{l}\text { Königstuhl Nappe- } \\
\text { Stangnock Formation }\end{array}$} & IGL14/19 & 407177 & 5195387 & 9 & 441 & 26 & & & & & \\
\hline & IGL14/36 & 412502 & 5200251 & 10 & 260 & 25 & 50 & 5.82 & 0.35 & 3.56 & 0.42 \\
\hline & IGL14/38 & 412806 & 5199904 & 10 & 279 & 25 & 30 & 6.23 & 0.54 & 3.47 & 0.70 \\
\hline & IGL14/39 & 412823 & 5199926 & 7 & 291 & 25 & 47 & 6.41 & 0.60 & 3.04 & 0.82 \\
\hline & IGL14/40 & 414320 & 5200554 & 10 & 283 & 25 & 50 & 5.43 & 0.57 & 2.18 & 0.57 \\
\hline & IGL14/42 & 415104 & 5199890 & 10 & 277 & 25 & 50 & 5.90 & 0.54 & 3.56 & 0.72 \\
\hline & IGL14/43 & 415216 & 5199591 & 10 & 275 & 25 & 50 & 5.83 & 0.49 & 3.67 & 0.64 \\
\hline & IGL14/46 & 410766 & 5201578 & 10 & 271 & 25 & 50 & 6.26 & 0.47 & 2.59 & 0.62 \\
\hline & IGL14/48 & 414454 & 5198005 & 9 & 274 & 25 & 50 & 6.16 & 0.42 & 3.75 & 0.63 \\
\hline & IGL14/49 & 413952 & 5197511 & 9 & 277 & 25 & & & & & \\
\hline & IGL14/50A & 414412 & 5197549 & 10 & 290 & 25 & 30 & 6.16 & 0.71 & 4.30 & 0.66 \\
\hline & IGL14/50B & 414412 & 5197549 & 10 & 253 & 25 & & & & & \\
\hline & IGL14/51 & 414646 & 5197525 & 7 & 246 & 25 & 50 & 5.26 & 0.27 & 4.07 & 0.31 \\
\hline & IGL14/52 & 414622 & 5197557 & 10 & 273 & 25 & 50 & 5.80 & 0.32 & 3.65 & 0.56 \\
\hline & IGL14/53 & 414796 & 5197594 & 10 & 292 & 25 & 50 & 5.58 & 0.42 & 4.53 & 0.49 \\
\hline & IGL14/54 & 415010 & 5197355 & 10 & 294 & 25 & 50 & 5.86 & 0.53 & 3.93 & 0.64 \\
\hline & IGL14/55 & 415070 & 5197240 & 10 & 252 & 25 & 50 & 5.57 & 0.40 & 4.08 & 0.41 \\
\hline & IGL14/56A & 414858 & 5196674 & 10 & 285 & 25 & 50 & 5.79 & 0.46 & 4.20 & 0.66 \\
\hline & IGL14/56B & 414858 & 5196674 & 10 & 256 & 25 & 50 & 5.47 & 0.46 & 4.04 & 0.51 \\
\hline & IGL14/61 & 411003 & 5200266 & 10 & 269 & 25 & 50 & 5.87 & 0.30 & 3.11 & 0.33 \\
\hline & IGL14/62 & 411025 & 5200262 & 10 & 251 & 25 & 50 & 6.15 & 0.55 & 3.86 & 0.43 \\
\hline & IGL15/04 & 416479 & 5200482 & 10 & 274 & 25 & 50 & 5.92 & 0.57 & 3.94 & 0.68 \\
\hline & IGL15/08 & 413475 & 5197937 & 10 & 273 & 25 & 30 & 4.96 & 0.14 & 4.46 & 0.20 \\
\hline & IGL15/30A & 421610 & 5197988 & 10 & 301 & 25 & 30 & 5.47 & 0.63 & 2.89 & 0.84 \\
\hline & IGL15/30B & 421610 & 5197988 & 10 & 320 & 25 & 32 & 4.84 & 0.59 & 2.24 & 0.54 \\
\hline & IGL15/31A & 421687 & 5198216 & 10 & 331 & 25 & & & & & \\
\hline & IGL16/08 & 425871 & 5211902 & 10 & 306 & 25 & & & & & \\
\hline & IGL16/23 & 423978 & 5210807 & 10 & 316 & 25 & & & & & \\
\hline & IGL16/28 & 421670 & 5199473 & 10 & 329 & 25 & & & & & \\
\hline & IGL16/30 & 421574 & 5199421 & 10 & 331 & 25 & & & & & \\
\hline & IGL16/59 & 420110 & 5201086 & 10 & 284 & 25 & & & & & \\
\hline & N55 & 405669 & 5199817 & 10 & 256 & 25 & & & & & \\
\hline & $\mathrm{T} 1$ & 414944 & 5196703 & 10 & 267 & 25 & 30 & 6.60 & & 2.50 & \\
\hline & $\mathrm{T} 2$ & 415054 & 5197212 & 10 & 302 & 25 & 30 & 6.90 & & 3.80 & \\
\hline & T3 & 414603 & 5197560 & 10 & 263 & 25 & 30 & 7.00 & & 3.20 & \\
\hline & $\mathrm{T} 4$ & 414267 & 5197069 & 9 & 266 & 25 & 30 & 6.50 & & 2.60 & \\
\hline
\end{tabular}


Table 1 (continued)

\begin{tabular}{|c|c|c|c|c|c|c|c|c|c|c|c|}
\hline \multirow{3}{*}{ Tectonic Unit } & \multirow{3}{*}{ Sample } & \multirow{3}{*}{ Easting } & \multirow{3}{*}{ Northing } & \multicolumn{3}{|c|}{ RSCM } & \multicolumn{5}{|c|}{ Vitrinite Reflectance } \\
\hline & & & & \multirow{2}{*}{$\mathbf{N}$} & \multicolumn{2}{|c|}{ Temp $\left({ }^{\circ} \mathrm{C}\right)$} & \multirow{2}{*}{$\mathbf{N}$} & \multicolumn{2}{|c|}{$R \max (\%)$} & \multicolumn{2}{|c|}{$\operatorname{Rmin}(\%)$} \\
\hline & & & & & median & cf & & mean & sd & mean & sd \\
\hline \multirow{8}{*}{$\begin{array}{l}\text { Stolzalpe Nappe - } \\
\text { Spielriegel Complex }\end{array}$} & IGL14/58 & 412453 & 5194143 & 10 & 309 & 25 & 30 & 7.33 & 0.94 & 1.93 & 0.99 \\
\hline & IGL14/59 & 412380 & 5194078 & 10 & 302 & 25 & & & & & \\
\hline & IGL14/60 & 414651 & 5193292 & 10 & 296 & 25 & & & & & \\
\hline & IGL15/02A & 415241 & 5199486 & 10 & 305 & 25 & 30 & 7.07 & 1.01 & 3.44 & 1.01 \\
\hline & IGL15/02B & 415241 & 5199486 & 10 & 320 & 25 & & & & & \\
\hline & IGL15/03A & 415224 & 5199536 & 10 & 309 & 25 & 30 & 7.38 & 0.69 & 3.76 & 0.88 \\
\hline & IGL15/03B & 415224 & 5199536 & 10 & 324 & 25 & & & & & \\
\hline & IGL18/14 & 426829 & 5197941 & 20 & 349 & 32 & & & & & \\
\hline \multirow{6}{*}{$\begin{array}{l}\text { Stolzalpe Nappe - } \\
\text { Stangnock Formation }\end{array}$} & IGL14/25 & 412164 & 5197592 & 10 & 250 & 25 & 30 & 5.59 & 0.49 & 4.46 & 0.59 \\
\hline & IGL14/26 & 412719 & 5197075 & 10 & 250 & 25 & 30 & 5.57 & 0.46 & 3.95 & 0.65 \\
\hline & IGL15/19 & 412117 & 5197496 & 10 & 235 & 25 & 40 & 5.59 & 0.45 & 3.71 & 0.53 \\
\hline & IGL15/20 & 412143 & 5197664 & 10 & 247 & 25 & 40 & 4.86 & 0.36 & 3.61 & 0.54 \\
\hline & IGL17/06B & 411483 & 5197112 & 10 & 249 & 25 & & & & & \\
\hline & GR17/01 & 412791 & 5196835 & 10 & 255 & 25 & & & & & \\
\hline
\end{tabular}

\begin{tabular}{|c|ccc|}
\hline Krappfeld Gosau - & G1 & 461631 & 5189626 \\
Eocene & G2 & 461413 & 5192611 \\
\cline { 1 - 3 } Krappfeld Gosau - & G3 & 464395 & 5187275 \\
Santonian- & G4 & 465209 & 5192493 \\
Maastrichtian & G5 & 464920 & 5191333 \\
& G6 & 460953 & 5190680 \\
G7 & 465981 & 5184909 \\
\hline
\end{tabular}

Vitrinite Reflectance
\begin{tabular}{|c|c|c|}
\hline N & \multicolumn{2}{|c|}{ Ro(\%) } \\
\cline { 2 - 3 } & mean & sd \\
\hline 50 & 0.21 & 0.02 \\
50 & 0.39 & 0.02 \\
50 & 0.43 & 0.06 \\
50 & 0.43 & 0.04 \\
50 & 0.42 & 0.04 \\
50 & 0.43 & 0.04 \\
50 & 0.48 & 0.05 \\
\hline
\end{tabular}

$N$ number of measurements, Temp RSCM temperature estimate, $c f 90 \%$ confidence interval) and vitrinite reflectance ( $s d$ standard deviation) of the investigated samples (Easting, Northing = coordinates in the UTM M33N system, EPSG 32633; RIS vitrinite reflectance estimated by the method of Kilby 1988)

on top of the lower greenschist- to amphibolite-facies metamorphic Variscan nappe stack. These sediments comprise the Middle to Late Pennsylvanian Stangnock Formation and the Cisuralian Werchzirm Formation (e.g. Krainer 1993). Erosion and Permian lithospheric extension (Schuster and Stüwe 2008) created a flat landscape that was flooded by a new transgressional cycle in the late Permian and Early Triassic. In the Triassic, thermal subsidence triggered the deposition of about $3000 \mathrm{~m}$ (e.g. Bechstädt 1978; Bauer et al. 1983) of mostly carbonate platform sediments (Schuster and Stüwe 2008). Burial and an elevated heat flow caused initial metamorphism in the Pennsylvanian sediments, as deduced from the 1D thermal model presented here. In the Jurassic, tectonic activity increased again due to the opening of the Penninic ocean (Alpine Tethys) and closure of the Neotethys ocean.

Thermal modeling results argue for a former proximity of the Stolzalpe Nappe cover to the Lienzer Dolomiten.
Consequently, the high heat flow estimate is in accordance to similar estimates from the paleogeographical adjacent Southalpine units (Rantitsch 1997; Bertotti et al. 1999) and explained by lithospheric extension within an instable continental margin during this time (Schuster and Stüwe 2008; Stüwe and Schuster 2010). As a result, the crystalline basement below the nappes of the Drauzug-Gurktal Nappe System was metamorphosed by Permian to Early Triassic high temperature - low pressure metamorphism (Schuster and Frank 1999; Schuster et al. 2015) and affected by intense magmatic activity (Schuster and Stüwe 2008; Miller et al. 2011; Knoll et al. 2018). Strongly elevated isotherms at upper crustal levels (Schuster et al. 2015) heated the Stangnock Formation during Permian extension and Triassic subsidence. After thrusting during Early to middle Late Cretaceous, cooling below $100{ }^{\circ} \mathrm{C}$ occurred still in the Late Cretaceous. 
Table 2 Stratigraphical input data of the thermal 1D model compiled from the Drauzug-Gurktal Nappe System units (van Bemmelen and Meulenkamp 1965; Krainer 1985, 1987, 1989; Appold 1989; Lein
1989; Neumann 1989; Wilkens 1989; Blau and Schmidt 1990; Blau and Grün 1995). The shaded values are thermal modeling assumptions

\begin{tabular}{|c|c|c|c|c|c|}
\hline Tectonic unit & Formation & $\begin{array}{l}\text { Thickness } \\
{[\mathrm{m}]}\end{array}$ & $\begin{array}{l}\text { Eroded } \\
\text { thickness [m] }\end{array}$ & Age & Depositional environment \\
\hline \multirow{7}{*}{$\begin{array}{l}\text { Königstuhl Nappe } \\
\text { and Stolzalpe Nappe } \\
\text { cover }\end{array}$} & $\begin{array}{l}\text { Stangnock Formation } \\
\text { Werchzirm Formation }\end{array}$ & $\begin{array}{l}400 \\
100\end{array}$ & & $\begin{array}{l}\text { Kasimovian-Gzhelian } \\
\text { Asselian }\end{array}$ & $\begin{array}{l}\text { fluviatile } \\
\text { debris flow, playa }\end{array}$ \\
\hline & Griffen Formation (Gröden Formation) & 100 & & Late Middle Permian & alluvial fan \\
\hline & Buntsandstein Formation & 200 & & Skyth & alluvial fan \\
\hline & Werfen Formation & 150 & & Skyth & shallow marine \\
\hline & Gutenstein Formatian & 200 & & Anisian & platform \\
\hline & Wetterstein Formation & 1000 & & Anisian-Ladinian & platform \\
\hline & Raibl Formation & 250 & & Carnian (Julian) & platform \\
\hline Lienzer Dolomiten & Hauptdolomite Formation & 1200 & 200 & Norian & platform \\
\hline \multirow{2}{*}{ Gailtaler Alpen } & Seefeld Formation & 80 & 80 & Norian & platform \\
\hline & Kössen Formation & 300 & 300 & Rhaetian & platform \\
\hline \multirow{4}{*}{ Lienzer Dolomiten } & Allgäu Formation & 300 & 300 & Hettnangian-Sinemurian & deep water \\
\hline & Rotkalk Formation & 20 & 20 & Pliensbachian-Kimmeridgian & deep water \\
\hline & Biancon & 20 & 20 & Tithon-Valanginian & deep water \\
\hline & Fleckenmergel & 20 & 20 & Valanginian-Aptian & platform \\
\hline \multirow{2}{*}{$\begin{array}{l}\text { Stolzalpe Nappe } \\
\text { cover }\end{array}$} & Gosau sediments & 1000 & 300 & Santonian-Campanian & deep water \\
\hline & Eocene sediments & 100 & & Paleocene-Eocene & platform \\
\hline
\end{tabular}

The Austroalpine nappes addressed in this study derive from different levels of the Adriatic continental crust and were assembled during the Eoalpine collision in the Cretaceous (Froitzheim et al. 2008; Schmid et al., 2004). The upper crustal part of the north-westerly located tectonic lower plate, including the post-Variscan cover, was stripped off in the Early Cretaceous and escaped intense metamorphism. In contrast, the main part was subducted, metamorphosed and exhumed in the middle Late Cretaceous to form the Koralpe-Wölz Nappe System, including the Gstoder Nappe. The frontal part of the upper plate was also stacked by WNW directed thrusting (Huet 2015) and formed the Ötztal-Bundschuh and Drauzug-Gurktal Nappe Systems (Froitzheim et al. 2008). During this process, the Stolzalpe Nappe overthrusted the Königstuhl Nappe along a WNWclimbing ramp. As a result, the Königstuhl Nappe was heated in a temperature profile of $>330^{\circ} \mathrm{C}$ at the base to ca. $250{ }^{\circ} \mathrm{C}$ at the top. According to the thrust direction, the burial temperature decreases towards the west. Both nappes were thrusted upon the less overprinted Pfannock Nappe. The nappes of the Drauzug-Gurktal Nappe System overthrusted the Bundschuh Nappe. Its Permo-Mesozoic cover (i.e. Stangalm Mesozoic), which was formerly characterized by a low rank of organic metamorphism (as preserved in the cover of the Stolzalpe Nappe; Rantitsch and Russegger 2000) was transformed to the semigraphite stage. Vitrinite reflectance increased from ca. 1.3\%Ro (Rantitsch and Russegger 2000) to ca. $6.4 \% \mathrm{Rmax}$ by heating to $410-564{ }^{\circ} \mathrm{C}$. The progressive metamorphic path towards the base is recorded by the presence of graphite in the underlying Bundschuh Nappe basement and Gstoder Nappe with temperatures above $550{ }^{\circ} \mathrm{C}$.
A special position is inferred for the Murau Nappe, which shows conditions similar like to those in the cover of the Bundschuh Nappe.

The $100-200{ }^{\circ} \mathrm{C}$ jump of RSCM temperature between the Gstoder, Bundschuh and Murau Nappes to the overlying nappes (Fig. 5) is interpreted as an effect of localized Late Cretaceous normal faulting during post-orogenic extension (Neubauer et al. 1987; Koroknai et al. 1999). Synchronously, the Krappfeld Gosau collapse basin formed on the top of the nappe stack and the whole section cooled down below greenschist-facies metamorphic conditions (e.g. Schuster and Frank 1999; Iglseder et al. 2018). The $100-200{ }^{\circ} \mathrm{C}$ jump therefore quantifies the amount of cooling due to post collision exhumation below large normal faults with top-to-theEast/Southeast kinematics. Final cooling occurred during the late Oligocene to Pliocene times (Neubauer et al. 2018; Bartusch and Stüwe 2019).

\section{Conclusions}

The present case study on organic metamorphism carried out in the Austroalpine unit allows us to draw the following methodological and tectonic conclusions:

Based on a thermometrically well-calibrated reference series (Lünsdorf et al. 2017), the automated IFORS peak fitting software of Lünsdorf and Lünsdorf (2016) estimates continuously very low- to low-grade metamorphic peak temperatures. The temperature estimates are validated by the application of independent methods up to at least $570{ }^{\circ} \mathrm{C}$. An uncertainty of ca. $\pm 25^{\circ} \mathrm{C}$ at a confidence level of 0.9 
accounts for the data variability within a sample location. Due to the large calibration range, the method is able to reconstruct a thermal crustal profile in time and threedimensional space.

During very low- to low-grade metamorphism, vitrinite reflectance is no longer a precise indicator of organic metamorphism at Rmax values higher than 5-7\%. In the study area, this rank is achieved in sub-greenschist-facies metamorphic rocks with peak temperatures above ca. $250{ }^{\circ} \mathrm{C}$. Above this value RSCM is a more reliable method to map metamorphic patterns.

At the northwestern margin of the Drauzug-Gurktal Nappe System (Eastern Alps), the RSCM temperature trend indicates a temperature profile of ca. $250-600{ }^{\circ} \mathrm{C}$ along an orogenic section, formed by sedimentary burial, progressive thrusting and normal faulting (Fig. 6). Conversely, organic maturation data track the temperature trend to near-surface levels. RSCM data characterize the Variscan metamorphic grade in nappes now imbricated in the Eoalpine nappe stack. They additionally constrain a numerical model which emphasizes the significance of an increased thermal gradient in the continental margin towards the western Neotethyan ocean during Permo-Triassic lithospheric extension. They finally characterize the Eoalpine metamorphic gradient during nappe stacking and the metamorphic jump related to exhumation due to normal faulting.

Acknowledgements Open access funding provided by Montanuniversität Leoben. Keno N. Lünsdorf (Göttingen, Germany) is gratefully acknowledged for providing the IFORS software and the calibration samples. Thomas Rainer provided the vitrinite reflectance data from the Krappfeld Gosau Basin. We thank Niko Froitzheim, Jan Pleuger and Peter Tropper for their constructive reviews that improved the quality of the paper.

Author contributions Gerd Rantitsch: Investigation, Data analysis, Writing, Illustration work. Christoph Iglseder: Investigation, Writing, Illustration work. Ralf Schuster: Writing, Review, Editing. Marianne Sophie Hollinetz: Investigation, Writing, Illustration work. Benjamin Huet: Investigation, Review, Editing. Manuel Werdenich: Investigation.

Funding This research is supported by the Geological Survey of Austria.

\section{Compliance with ethical standards}

Conflicts of interest The authors declare that they have no conflicts of interest and no competing interests.

Availability of data and material The processed study data are presented in the manuscript. Raw data are available by request.

Code availability The IFORS software is available at https://www. sediment.uni-goettingen.de/download/

Open Access This article is licensed under a Creative Commons Attribution 4.0 International License, which permits use, sharing, adaptation, distribution and reproduction in any medium or format, as long as you give appropriate credit to the original author(s) and the source, provide a link to the Creative Commons licence, and indicate if changes were made. The images or other third party material in this article are included in the article's Creative Commons licence, unless indicated otherwise in a credit line to the material. If material is not included in the article's Creative Commons licence and your intended use is not permitted by statutory regulation or exceeds the permitted use, you will need to obtain permission directly from the copyright holder. To view a copy of this licence, visit http://creativecommons .org/licenses/by/4.0/.

\section{References}

Angiboust S, Agard P, Jolivet L, Beyssac O (2009) The Zermatt-Saas ophiolite: the largest (60-km wide) and deepest (c. 70-80 km) continuous slice of oceanic lithosphere detached from a subduction zone? Terra Nova 21:171-180. https://doi.org/10.111 1/j.1365-3121.2009.00870.x

Appold T (1989) Die Permotrias des Krappfeld. Arbeitstagung der Geologischen Bundesanstalt 1989, Blatt 186 St. Veit an der Glan, Wien 45-60

Bartusch T, Stüwe K (2019) Evidence for pre-Pleistocene landforms in the Eastern Alps. Geomorphological constraints from the Gurktal Alps. Austrian J Earth Sci 112:84-102. https://doi.org/10.17738 /ajes.2019.0006

Barzoi SC (2015) Shear stress in the graphitization of carbonaceous matter during the low-grade metamorphism from the northern Parang Mountains (South Carpathians) - Implications to graphite geothermometry. Int J Coal Geol 146:179-187. https://doi. org/10.1016/j.coal.2015.05.008

Bauer FK, Cerny I, Exner C, Holzer H-L, van Husen D, Loeschke J, Suette G, Tessensohn F (1983) Erläuterungen zur geologischen Karte der Karawanken 1:25:000. Ostteil. Geologische Bundesanstalt, Wien

Bechstädt T (1978) Faziesanalyse permischer und triadischer Sedimente des Drauzuges als Hinweis auf eine großräumige Lateralverschiebung innerhalb des Ostalpin. Jahrbuch der Geologischen Bundesanstalt 121:1-121

Bertotti G, Picotti V, Bernoulli D, Castellarin A (1993) From rifting to drifting: tectonic evolution of the South-Alpine upper crust from the Triassic to the Early Cretaceous. Sed Geol 86:53-76. https://doi.org/10.1016/0037-0738(93)90133-P

Bertotti G, Seward D, Wijbrans J, ter Voorde M, Hurford AJ (1999) Crustal thermal regime prior to, during, and after rifting: A geochronological and modeling study of the Mesozoic South Alpine rifted margin. Tectonics 18:185-200. https://doi. org/10.1029/1998TC900028

Beyssac O, Rouzaud J-N, Goffé B, Brunet F, Chopin C (2002a) Graphitization in a high-pressure, low-temperature metamorphic gradient: a Raman microspectroscopy and HRTEM study. Contrib Miner Petrol 143:19-31. https://doi.org/10.1007/s0041 0-001-0324-7

Beyssac O, Goffé B, Chopin C, Rouzaud JN (2002b) Raman spectra of carbonaceous material in metasediments: a new geothermometer. J Metamorph Geol 20:859-871. https://doi.org/10.1 046/j.1525-1314.2002.00408.x

Blau J, Grün B (1995) Jura und Kreide in der Amlacher Wiesen Mulde (Nördliche Lienzer Dolomiten). Arbeitstagung 1995 der Geologischen Bundesanstalt, Geologie von Osttirol, Geologische Bundesanstalt, Wien, pp 43-66 
Blau J, Schmidt T (1990) Zur Stratigraphie des oberen Hauptdolomits (Nor) der Lienzer Dolomiten (Osttirol, Österreich). Geologisch-paläontologische Mitteilungen Innsbruck 17:1-23

Bousquet R, Oberhänsli R, Schmid SM, Berger A, Wiederkehr M, Robert C, Möller A, Rosenberg C, Koller F, Molli G, Zeilinger G (2012) Metamorphic framework of the Alps. CCGM/ CGMW, https://www.geodynalps.org

Buseck PR, Huang B-J (1985) Conversion of carbonaceous material to graphite during metamorphism. Geochim Cosmochim Acta 49:2003-2016. https://doi.org/10.1016/0016-7037(85)90059-6

Coggon R, Holland TJ (2002) Mixing properties of phengitic micas and revised garnet-phengite thermobarometers. J Metamorph Geol 20:683-696. https://doi.org/10.104 6/j.1525-1314.2002.00395.x

De Capitani C, Petrakakis K (2010) The computation of equilibrium assemblage diagrams with Theriak/Domino software. Am Miner 95:1006-1016. https://doi.org/10.2138/am.2010.3354

Diessel C, Offler R (1975) Change in physical properties of coalified and graphitised phytoclasts with grade of metamorphism. Neues Jahrbuch für Mineralogie Monatshefte 1975:11-26

Dunkl I, Antolín B, Wemmer K, Rantitsch G, Kienast M, Montomoli C, Ding L, Carosi R, Appel E, El Bay R, Xu Q, von Eynatten H (2011) Metamorphic evolution of the Tethyan Himalayan flysch in SE Tibet. Geolog Soc London Special Public 353:45-69. https ://doi.org/10.1144/SP353.4

Fauconnier J, Labrousse L, Andersen TB, Beyssac O, Duprat-Oualid S, Yamato P (2014) Thermal structure of a major crustal shear zone, the basal thrust in the Scandinavian Caledonides. Earth Planet Sci Lett 385:162-171. https://doi.org/10.1016/j.epsl.2013.10.038

Ferreiro Mählmann R (2001) Correlation of very low grade data to calibrate a thermal maturity model in a nappe tectonic setting, a case study from the Alps. Tectonophysics 334:1-33. https://doi. org/10.1016/S0040-1951(01)00022-1

Ferreiro Mählmann R, Le Bayon R (2016) Vitrinite and vitrinite like solid bitumen reflectance in thermal maturity studies: Correlations from diagenesis to incipient metamorphism in different geodynamic settings. Int J Coal Geol 157:52-73. https://doi. org/10.1016/j.coal.2015.12.008

Ferreiro Mählmann R, Bozkaya Ö, Potel S, Le Bayon R, Šegvić B, Nieto F (2012) The pioneer work of Bernard Kübler and Martin Frey in very low-grade metamorphic terranes: paleo-geothermal potential of variation in Kübler-Index/organic matter reflectance correlations A review. Swiss J Geosci 105:121-152. https://doi. org/10.1007/s00015-012-0115-3

Frey M, Desmons J, Neubauer F (1999) The new metamorphic map of the Alps. Schweiz Mineral Petrogr Mitt 79:1-4

Frimmel HE (1988) Metagranitoide am Westrand der Gurktaler Decke (Oberostalpin): Genese und paläotektonische Implikationen. Jahrbuch der Geologischen Bundesanstalt 131:575-592

Froitzheim N, Plašienka D, Schuster R (2008) Alpine tectonics of the Alps and Western Carpathians. In: McCann T (ed) The Geology of Central Europe. Vol 2: Mesozoic and Cenozoic. Geological Society of London, pp 1141-1232

Fügenschuh B, Mancktelow NS, Seward D (2000) Cretaceous to Neogene cooling and exhumation history of the Oetztal-Stubai basement complex, eastern Alps. Tectonics 19:905-918. https://doi. org/10.1029/2000TC900014

Fuhrman ML, Lindsley DH (1988) Ternary-feldspar modeling and thermometry. Am Miner 73:201-215

Haas J, Kovács S, Krystyn L, Lein R (1995) Significance of Late Permian-Triassic facies zones in terrane reconstructions in the Alpine-North Pannonian domain. Tectonophysics 242:19-40. https://doi.org/10.1016/0040-1951(94)00157-5

Haas I, Eichinger S, Haller D, Fritz H, Nievoll J, Mandl M, Hippler D, Hauzenberger C (2020) Gondwana fragments in the Eastern
Alps: A travel story from $\mathrm{U} / \mathrm{Pb}$ zircon data. Gondwana Res 77:204-222. https://doi.org/10.1016/j.gr.2019.07.015

Hantschel T, Kauerauf AI (2009) Fundamentals of basin and petroleum systems modeling. Springer, Berlin

Hejl E (1984) Geochronologische und petrologische Beiträge zur Gesteinsmetamorphose der Schladminger Tauern. Mitteilungen der Gesellschaft der Geologie- und Bergbaustudenten Österreichs 32:39-65

Henry DG, Jarvis I, Gillmore G, Stephenson M (2019) Raman spectroscopy as a tool to determine the thermal maturity of organic matter: Application to sedimentary, metamorphic and structural geology. Earth Sci Rev 198:102936. https://doi.org/10.1016/j. earscirev.2019.102936

Hoinkes G, Koller F, Rantitsch G, Dachs E, Höck V, Neubauer F, Schuster R (1999) Alpine metamorphism of the Eastern Alps. Schweiz Mineral Petrogr Mitt 79:155-181

Holland T, Powell R (2011) An improved and extended internally consistent thermodynamic dataset for phases of petrological interest, involving a new equation of state for solids. J Metamorph Geol 29:333-383. https://doi.org/10.1111/j.1525-1314.2010.00923.x

Huet B (2015) Strukturgeologie der Stolzalpe-Decke auf Blatt Radenthein-Ost (UTM 3106). Jahrbuch der Geologischen Bundesanstalt 155:121-145

Iglseder C (2019) Geologische und tektonische Karte der Gurktaler Alpen 1:250.000. In: Griesmeier GEU, Iglseder C (eds) Arbeitstagung 2019 der Geologischen Bundesanstalt - Geologie des Kartenblattes GK25 Radenthein-Ost. Geologische Bundesanstalt, Wien, pp 48-54

Iglseder Ch, Huet B, Rantitsch G, Ratschbacher L, Pfänder J (2016) Age and structure of the Stolzalpe Nappe - evidence for Variscan metamorphism, Eoalpine top-to-the-WNW thrusting and top-tothe-ESE normal faulting (Gurktal Alps, Austria). In: Ortner H (ed) Abstract Volume of GeoTirol 2016, Innsbruck, p 137

Iglseder C, Huet B, Schuster R, Rantitsch G, Dunkl I, Ratschbacher L (2018) A section through the uppermost Upper Austroalpine Insights from the Gstoder, Bundschuh, Königstuhl and Stolzalpe Nappes (Gurktal Alps, Austria). Berichte der Geologischen Bundesanstalt 128:66

Iglseder C, Van Husen D, Huet B, Knoll T, Schönlaub H-P (2019) Geologische Karte der Republik Österreich 1:25.000, Blatt Radenthein-Nordost, Geologische Bundesanstalt, Wien

Janák M, Froitzheim N, Yoshida K, Sasinková V, Nosko M, Kobayashi T, Hirajima T, Vrabec M (2015) Diamond in metasedimentary crustal rocks from Pohorje, Eastern Alps. J Metamorph Geol 33:495-512. https://doi.org/10.1111/jmg.12130

Kaindl R, Abart R (2002) Reequilibration of fluid inclusions in garnet and kyanite from metapelites of the Radenthein Complex, Austroalpine Basement, Austria. Schweiz Mineral Petrogr Mitt $82: 467-486$

Kilby WE (1988) Recognition of vitrinite with non-uniaxial negative reflectance characteristics. Int J Coal Geol 9:267-285. https:// doi.org/10.1016/0166-5162(88)90017-1

Knoll T, Schuster R, Huet B, Mali H, Onuk P, Horschinegg M, Ertl A, Giester G (2018) Spodumene pegmatites and related leucogranites from the AustroAlpine unit (Eastern Alps, Central Europe): field relations, petrography, geochemistry, and geochronology. Canadian Mineral 56:489-528. https://doi.org/10.3749/canmi n. 1700092

Koch J, Günther M (1995) Relationship between random and maximum vitrinite reflectance. Fuel 74:1687-1691. https://doi. org/10.1016/0016-2361(95)00111-H

Koroknai B, Neubauer F, Genser J, Topa D (1999) Metamorphic and tectonic evolution of Austroalpine units at the western margin of the Gurktal nappe complex, Eastern Alps. Schweiz Mineral Petrogr Mitt 79:277-295 
Krainer K (1985) Zur Sedimentologie des Alpinen Buntsandsteins und der Werfener Schichten (Skyth) Kärntens. Geologisch-paläontologische Mitteilungen Innsbruck 14:21-81

Krainer K (1987) Das Perm der Gurktaler Decke: eine sedimentologische Analyse. Carinthia II 177(97):49-92

Krainer K (1989) Das Karbon in Kärnten Carinthia II 179(99):59-109

Krainer K (1993) Late- and Post-Variscian sediments of the Eastern and Southern Alps. In: Neubauer F, Raumer JF (eds) The preMesozoic Geology of the Alps. Springer, Berlin, Heidelberg, New York, pp 537-564

Krenn K, Fritz H, Mogessi A, Schaflechner J (2008) Late Cretaceous exhumation history of an extensional extruding wedge (Graz Paleozoic Nappe Complex, Austria). Int J Earth Sci 97:13311352. https://doi.org/10.1007/s00531-007-0221-z

Kribek B, Hrabal J, Landais P, Hladikova J (1994) The association of poorly ordered graphite, coke and bitumens in greenschist facies rocks of the Ponikla Group, Lugicum, Czech Republic: the result of graphitization of various types of carbonaceous matter. J Metamorph Geol 12:493-503. https://doi. org/10.1111/j.1525-1314.1994.tb00038.x

Kwiecińska B, Petersen H (2004) Graphite, semi-graphite, natural coke, and natural char classification - ICCP system. Int J Coal Geol 57:99-116. https://doi.org/10.1016/j.coal.2003.09.003

Lanari P, Duesterhoeft E (2019) Modeling metamorphic rocks using equilibrium thermodynamics and internally consistent databases: past achievements, problems and perspectives. J Petrol 60:19-56. https://doi.org/10.1093/petrology/egy105

Lein R (1989) Die karbonatische Triasentwicklung (Anis-Nor) des Krappfeldes. In: Appold T, Thiedig F (eds) Arbeitstagung der Geologischen Bundesanstalt 1989, Blatt 186 St. Veit an der Glan, Geologische Bundesanstalt, Wien, pp 61-69

Lein R, Gawlick H-J, Krystyn L (1997) Paläogeographie und tektonische Herkunft des Drauzuges - Eine Diskussion auf der Basis von Fazies- und Conodont Colour Alteration Index (CAI)Untersuchungen. Zentralblatt Geologie Paläontologie Teil I 1996:471-483

Lünsdorf NK (2016) Raman spectroscopy of dispersed vitrinite Methodical aspects and correlation with reflectance. Int J Coal Geol 153:75-86. https://doi.org/10.1016/j.coal.2015.11.010

Lünsdorf NK, Lünsdorf JO (2016) Evaluating Raman spectra of carbonaceous matter by automated, iterative curve-fitting. Int J Coal Geol 160-161:51-62. https://doi.org/10.1016/j. coal.2016.04.008

Lünsdorf NK, Dunkl I, Schmidt BC, Rantitsch G, von Eynatten H (2012) The thermal history of the Steinach Nappe (eastern Alps) during extension along the Brenner Normal Fault system indicated by organic maturation and zircon (U-Th)/ He thermochronology. Austrian J Earth Sci 105:17-25

Lünsdorf NK, Dunkl I, Schmidt BC, Rantitsch G, von Eynatten H (2014) Towards a higher comparability of geothermometric data obtained by Raman spectroscopy of carbonaceous material. Part I: Evaluation of biasing factors. Geostand Geoanal Res 38:73-94. https://doi.org/10.1111/j.1751-908X.2013.12011.x

Lünsdorf NK, Dunkl I, Schmidt BC, Rantitsch G, von Eynatten H (2017) Towards a higher comparability of geothermometric data obtained by Raman spectroscopy of carbonaceous material. Part 2: A revised geothermometer. Geostand Geoanal Res 41:593612. https://doi.org/10.1111/ggr.12178

Miller C, Thöni M, Goessler W, Tessadri R (2011) Origin and age of the Eisenkappel gabbro to granite suite (Carinthia, SE Austrian Alps). Lithos 125:434-448. https://doi.org/10.1016/j.litho s.2011.03.003

Neubauer F (1980) Zur tektonischen Stellung des Ackerlkristallins (Nordrand der Gurktaler Decke). Mitteilungen der österreichischen geologischen Gesellschaft 73:39-53
Neubauer F (1987) The Gurktal Thrust System within the Austroalpine region - some structural and geometrical aspects. In: Flügel HW, Faupl P (eds) Geodynamics of the Eastern Alps. Deuticke, Wien, pp 226-236

Neubauer F, Dallmeyer RD (1994) The Ackerl Metamorphic Complex: a late Variscan metamorphic nappe within the Austroalpine Unit of the Eastern Alps. J Czech Geolog Soc 39:77-78

Neubauer F, Pistotnik J (1984) Das Altpaläozoikum und Unterkarbon des Gurktaler Deckensystems (Ostalpen) und ihre paläogeographischen Beziehungen. Geol Rundsch 73:149-174

Neubauer F, Dallmeyer RD, Dunkl I, Schirnik D (1995) Late Cretaceous exhumation of the metamorphic Gleinalm dome, Eastern Alps: kinematics, cooling history and sedimentary response in a sinistral wrench corridor. Tectonophysics 242:79-98. https:// doi.org/10.1016/0040-1951(94)00154-2

Neubauer FR, Genser J, Handler R (2003) Tectonic Evolution of the western margin of the Gurktal nappe complex, Eastern Alps: Constraints from structural studies and $40 \mathrm{Ar} / 39 \mathrm{Ar}$ white mica ages. Mitteilungen der Österreichischen Mineralogischen Gesellschaft 148:240-241

Neubauer F, Heberer B, Dunkl I, Liu X, Bernroider M, Dong Y (2018) The Oligocene Reifnitz tonalite (Austria) and its host rocks: implications for Cretaceous and Oligocene-Neogene tectonics of the south-eastern Eastern Alps. Geol Carpath 69:237-253. https://doi.org/10.1515/geoca-2018-0014

Neumann H-H (1989) Die Oberkreide des Krappfeldes. In: Appold T, Thiedig F (eds) Arbeitstagung der Geologischen Bundesanstalt 1989, Blatt 186 St. Veit an der Glan, Geologische Bundesanstalt, Wien, pp 70-79

Oberhänsli R, Bousque R, Engi M, Goffe B, Gosso G, Handy M, Koller F, Lardeaux JM, Polino R, Rossi P, Schuster R, Schwartz S, Spalla IE, Agard P, Babist J, Berger A, Bertle R, Bucher S, Burri T, Heitzmann P, Hoinkes G, Jolivet L, Keller L, Linner M, Lombardo B, Martinotti G, Michard A, Pestal G, Proyer A, Rantisch G, Rosenberg C, Schramm J, Sölva H, Thöni M, Zucali M (2004) Metamorphic structure of the Alps 1:1.000.000. Commission of the Geologic map of the World, Paris

Piller WE (2014) The Lithostratigraphic Units of the Austrian Stratigraphic Chart 2004 (Sedimentary Successions) - Volume 1: The Paleozoic Era(them). Abhandlungen der Geologischen Bundesanstalt 66:1-136

Pistotnik J (1973/74). Zur Geologie des NW-Randes der Gurtaler Masse (Stangalm-Mesozoikum, Österreich). Mitteilungen der österreichischen geologischen Gesellschaft. 66-67:127-141

Plunder A, Agard P, Dubacq B, Chopin C, Bellanger M (2012) How continuous and precise is the record of P-T paths? Insights from combined thermobarometry and thermodynamic modelling into subduction dynamics (Schistes Lustrés, W. Alps). J Metamorph Geol 30:323-346. https://doi.org/10.111 $1 / \mathrm{j} .1525-1314.2011 .00969 . x$

Rainer T, Sachsenhofer RF, Green PF, Rantitsch G, Herlec U, Vrabec M (2016) Thermal maturity of Carboniferous to Eocene Sediments of the Alpine-Dinaric Transition Zone (Slovenia). Int J Coal Geol 157:19-38. https://doi.org/10.1016/j.coal.2015.08.005

Rantitsch G (1995) Niedrigstgradige Metamorphose im Karbon von Nötsch (Österreich). Jahrbuch der Geologischen Bundesanstalt 138:433-440

Rantitsch G (1997) Thermal history of the Carnic Alps (Southern Alps, Austria) and its palaeogeographic implications. Tectonophysics 272:213-232. https://doi.org/10.1016/S0040-1951(96)00259-4

Rantitsch G (2001) Thermal history of the Drau Range (Eastern Alps). Schweiz Mineral Petrogr Mitt 81:181-196

Rantitsch G, Judik K (2009) Alpine metamorphism in the central segment of the Western Greywacke Zone (Eastern Alps). Geol Carpath 60:319-329. https://doi.org/10.2478/v10096-009-0023-2 
Rantitsch G, Rainer T (2003) Thermal modeling of Carboniferous to Triassic sediments of the Karawanken Range (Southern Alps) as a tool for paleogeographic reconstructions in the Alpine-Dinaridic-Pannonian realm. Int J Earth Sci 92:195-209. https://doi. org/10.1007/s00531-003-0312-4

Rantitsch G, Russegger B (2000) Thrust-related very low grade metamorphism within the Gurktal Nappe Complex (Eastern Alps). Jahrbuch der Geologischen Bundesanstalt 142:219-225

Rantitsch G, Grogger W, Teichert Ch, Ebner F, Hofer C, Maurer E-M, Schaffer B, Toth M (2004) Conversion of carbonaceous material to graphite within the Greywacke Zone of the Eastern Alps. Int J Earth Sci 93:959-973. https://doi.org/10.1007/s0053 1-004-0436-1

Rantitsch G, Sachsenhofer RF, Hasenhüttl Ch, Russegger B, Rainer T (2005) Thermal evolution of an extensional detachment as constrained by organic metamorphic data and thermal modeling: Graz Paleozoic Nappe Complex (Eastern Alps). Tectonophysics 411:57-72. https://doi.org/10.1016/j.tecto.2005.08.022

Rantitsch G, Lämmerer W, Fisslthaler E, Mitsche S, Kaltenböck H (2016) On the discrimination of semi-graphite and graphite by Raman spectroscopy. Int J Coal Geol 159:48-56. https://doi. org/10.1016/j.coal.2016.04.001

Ratschbacher L, Neubauer F (1989) West-directed décollement of Austro-Alpine cover nappes in the eastern Alps. Geological Society, London, Special Publications 45:243-262. https://doi. org/10.1144/GSL.SP.1989.045.01.14

Ratschbacher L, Frisch W, Neubauer F, Schmid SM, Neugebauer J (1989) Extension in compressional orogenic belts: The eastern Alps. Geology 17:404-407. https://doi.org/10.1130/00917613(1989)017<0404:EICOBT>2.3.CO;2

Scharf A, Handy MR, Ziemann MA, Schmid SM (2013) Peak-temperature patterns of polyphase metamorphism resulting from accretion, subduction and collision (eastern Tauern Window, European Alps) - a study with Raman microspectroscopy on carbonaceous material (RSCM). J Metamorph Geol 31:863-880. https://doi.org/10.1111/jmg.12048

Schimana R (1986) Neue Ergebnisse zur Entwicklungsgeschichte des Kristallins um Radenthein (Kärnten, Österreich). Mitteilungen der Gesellschaft der Geologie und Bergbaustudenten Österreichs 33:221-232

Schmid SM, Fügenschuh B, Kissling E, Schuster R (2004) Tectonic map and overall architecture of the Alpine orogen. Eclogae Geol Helv 97:93-117. https://doi.org/10.1007/s00015-004-1113-x

Schmidt Th, Blau J, Kázmér M (1991) Large-scale strike-slip displacement of the Drauzug and the Transdanubian Mountains in early Alpine history: Evidence from permo-mesozoic facies belts. Tectonophysics 200:213-232. https://doi.org/10.1016/00401951(91)90016-L

Schmidt Th, Blau J, Grösser J, Heinisch H (1993) Die Lienzer Dolomiten als integraler Bestandteil der dextralen Periadriatischen Scherzone. Jahrbuch der Geologischen Bundesanstalt 136:223-232

Schönlaub H-P (2014) Stangnock-Formation. In: Piller WE (ed) The lithostratigraphic units of the Austrian stratigraphical chart 2004 (sedimentary successions). Vol. 1. The Paleozoic Era(them). Abhandlungen der Geologischen Bundesanstalt 66:39-41

Schramm J-M, von Gosen W, Seeger M, Thiedig F (1982) Zur Metamorphose variszischer und postvariszischer Feinklastika in Mittel- und Ostkärnten (Österreich). Mitteilungen aus dem Geologisch-Paläontologischen Instituts der Universität Hamburg 53:169-179

Schuster R, Frank W (1999) Metamorphic evolution of the Austroalpine units east of the Tauern Window: indications for Jurassic strike slip tectonics. Mitteilungen der Gesellschaft der Geologie und Bergbaustudenten Österreichs 42:37-58

Schuster R, Stüwe K (2008) Permian metamorphic event in the Alps. Geology 36:603-606. https://doi.org/10.1130/G24703A.1

Schuster R, Tropper P, Krenn E, Finger F, Frank W, Philippitsch R (2015) Prograde Permo-Triassic metamorphic HT/LP assemblages from the Austroalpine Jenig Complex (Carinthia, Austria). Austrian J Earth Sci 108:73-90. https://doi.org/10.17738 /ajes.2015.0005

Souche A, Beyssac O, Andersen TB (2012) Thermal structure of supra-detachment basins: a case study of the Devonian basins of western Norway. J Geolog Soc 169:427-434. https://doi. org/10.1144/0016-76492011-155

Stüwe K, Schuster R (2010) Initiation of subduction in the Alps: Continent or ocean? Geology 38:175-178. https://doi.org/10.1130/ G30528.1

Sweeney JJ, Burnham AK (1990) Evaluation of a simple model of vitrinite reflectance based on chemical kinetics. Am Asso Petrol Geol Bull 74:1559-1570

Thöni M (1999) A review of geochronological data from the Eastern Alps. Schweiz Mineral Petrogr Mitt 79:209-230

Tollmann A (1977) Geologie von Österreich, vol I. Die Zentralalpen, Deuticke, Wien

Vacherat A, Mouthereau F, Pik R, Bernet M, Gautheron C, Masini E, Le Pourhiet L, Tibari B, Lahfid A (2014) Thermal imprint of rift-related processes in orogens as recorded in the Pyrenees. Earth Planet Sci Lett 408:296-306. https://doi.org/10.1016/j. eps1.2014.10.014

van Bemmelen RW, Meulenkamp JE (1965) Beiträge zur Geologie des Drauzuges (Kärnten, Österreich). Jahrbuch der Geologischen Bundesanstalt 108:213-268

van Hinte JE (1963) Zur Stratigraphie und Mikropaläontologie der Oberkreide und des Eozäns des Krappfeldes (Kärnten). Jahrbuch der Geologischen Bundesanstalt, Sonderband 8:1-147

von Gosen W (1989) Gefügeentwicklungen, Metamorphosen und Bewegungen der ostalpinen Baueinheiten zwischen Nockgebiet und Karawanken (Österreich). Geotekton Forsch 72:1-247

von Gosen W, Haiges K-H, Neubauer F, Pistotnik J, Thiedig F (1985) Die tektonischen Baueinheiten am Nord- und Westrand der Gurktaler Decke (Österreich). Jahrbuch der Geologischen Bundesanstalt 127:693-699

von Gosen W, Pistotnik J, Schramm J-M (1987) Schwache Metamorphose in Gesteinsserien des Nockgebietes und im Postvariszikum des Karawankenvorlandes (Ostalpen, Kärnten). Jahrbuch der Geologischen Bundesanstalt 130:31-36

Whitney D, Evans B (2010) Abbreviations for names of rock-forming minerals. Am Miner 95:185-187. https://doi.org/10.2138/ am.2010.3371

Wilkens E (1989) Paläogene Sedimente des Krappfeldes und seiner Umgebung. In: Appold T, Thiedig F (eds) Arbeitstagung der Geologischen Bundesanstalt 1989, Blatt 186 St. Veit an der Glan, Geologische Bundesanstalt, Wien, pp 85-99

Wopenka B, Pasteris JD (1993) Structural characterization of kerogens to granulite-facies graphite: applicability of Raman microprobe spectroscopy. Am Miner 78:533-557

Zerlauth M, Bertrand A, Rantitsch G, Groß D, Ortner H, Pomella H, Fügenschuh B (2016) Thermal history of the westernmost Eastern Alps (Penninic Rhenodanubian Flysch nappes, Helvetic nappes, and Subalpine Molasse thrust sheets). Int J Earth Sci 105:1525-1547. https://doi.org/10.1007/s00531-015-1267-y 